\title{
New group, new species and new records from Brazil of the atropos, brasilianus and giganteus groups (Blattaria, Blaberidae, Blaberinae)
}

\author{
Sonia Maria Lopes ${ }^{1,2,3}$ \& Edivar Heeren de Oliveira ${ }^{1}$ \\ ${ }^{I}$ Departamento de Entomologia, Museu Nacional, Universidade Federal do Rio de Janeiro - UFRJ, \\ Quinta da Boa Vista, s/n, São Cristóvão, CEP 20949-040, Rio de Janeiro, RJ, Brasil \\ ${ }^{2} \mathrm{CNPq}$ Researcher \\ ${ }^{3}$ Corresponding author: Sonia Maria Lopes, e-mail: sonialfraga@gmail.com
}

LOPES, S.M. \& OLIVEIRA, E.H. New group, new species and new records from Brazil of the atropos, brasilianus and giganteus groups (Blattaria, Blaberidae, Blaberinae). Biota Neotrop. (13)2: http://www. biotaneotropica.org.br/v13n3/en/abstract?short-communication+bn03413022013

\begin{abstract}
This paper presents 20 species of the genus Blaberus (Blaberidae) included in the atropos, brasilianus and giganteus groups. A new group is defined, and 12 new species are described. The genitalia of the eight known species are described. The descriptions are based on the morphology of the head, thorax and abdomen, illustrating the structures of the genitalia and variations in the form of the structures, some within the same species. New records for five known species are discussed. All material is deposited in the collection of the Museu Nacional of Rio de Janeiro.
\end{abstract}

Keywords: Blattaria, morphology, diversity, new taxon, taxonomy.

LOPES, S.M. \& OLIVEIRA, E.H. Novo grupo, novas espécies e novos registros para o Brasil pertencentes aos grupos atropos, brasilianus e giganteus (Blattaria, Blaberidae, Blaberinae). Biota Neotrop. (13)2: http:// www.biotaneotropica.org.br/v13n3/pt/abstract?short-communication+bn03413022013

Resumo: Este trabalho apresenta vinte espécies do gênero Blaberus incluídas nos grupos atropos, brasilianus e giganteus. Um novo grupo é apresentado. Dessas espécies são descritas doze como novas espécies. São descritas as genitálias de oito espécies já conhecidas. As descrições são baseadas em caracteres morfológicos de cabeça, tórax e abdomen com ilustração das estruturas das genitálias e variações na forma de suas estruturas em algumas delas dentro da mesma espécie, bem como novos registros para cinco espécies já conhecidas. Todo o material está depositado na coleção do Museu Nacional do Rio de Janeiro.

Palavras-chave: Blattaria, morfologia, diversidade, novo táxon, taxonomia. 


\section{Introduction}

The family Blaberidae Brunner de Wattenwyl (1865) includes small- to large-sized species; the former have the tegmina and wings extending over the apex of the abdomen, and are apterous or subapterous; and the latter are medium-to-large sized with green, brown or black tegmina. The family is the most evolved among the Blattaria, and its individuals show such a close resemblance that although they have undergone adaptations, they retain elements of the genitalia and proventriculus with only small variations (McKittrick, 1964).

Roth (2003) characterized the males of this family as having cerci that are usually small, segmented or not, and not reaching the posterior margin of the supra-anal plate; with two similar, simple, small styles, rarely one or both absent. The genital hook is located on the right side, and is rarely reduced or absent. The females have a widened atrium in which the eggs are incubated. The majority of the species are ovoviviparous, rarely viviparous or with the ootheca absent.

Within the genus Blaberus Serville (1831), of which B. giganteus Linnaeus is the type-species, the great diversification of its species makes it desirable to study the described species as well as those that are new to science. Burmeister, 1838 (in: Princis, 1946) first mentioned the presence of spines on the prepuce in B. trapezoideus Burmeister, 1838, and Hebard (1917) also mentioned these spines in B. craniifer Burmeister, 1838 and B. atropos (Stoll, 1813). Princis (1946) illustrated the structure of the aedeagus and the prepuce of $B$. giganteus (Linnaeus, 1758), B. trapezoideus, B. atropos, B. craniifer, B. discoidalis Serville, 1839, B. parabolicus Walker, 1868, B. anisitsi Brancsik, 1898 and B. boliviensis Princis, 1946.

Leféuvre (1960) illustrated the genitalia of $B$. craniifer. McKittrick (1964) illustrated B. discoidalis. Drawing upon the structure of the prepuce and the aedeagus, Roth (1969) classified the species of Blaberus into three groups: 1$)$ giganteus (B. giganteus and B. craniifer); 2) Brasilianus (B. minor Saussure, 1864, B. brasilianus Saussure, 1864, B. colosseus Illliger, 1801, B. fusiformis Walker, 1868, B. scutatus Saussure \& Zehntner, 1894); and 3) atropos (B. atropos, B. parabolicus, B. discoidalis, B. anisitsi and B. boliviensis). Roth (1969) regarded $B$. trapezoideus as synonymous with $B$. giganteus and $B$. colosseus. He added that the intra-specific variation of the genitalia is so great that it is difficult and sometimes even impossible to distinguish these structures among certain species of one group. Pellens \& Grandcolas (2008) distinguished four species of the brasilianus group within Brazil, and Beccaloni (2012) listed 19 species for the genus.

The present report illustrates the habitus and the structures of the genitalia of males belonging to 20 species of Blaberus included in the atropos, brasilianus and giganteus groups. Interspecific differences and intra-specific variations in the habitus and morphology of the head and pronotum, reinforced by the configuration of the structure of the genitalia, including the median sclerite, right phallomere and left phallomere, are described. The following groups of species and their variations are presented: in the atropos group, $B$. atropos with six variations, $B$. duckey, B. matogrossensis, B. parabolicus with six variations. Also, five new species are described. New records from Brazil are provided for B. atropos and B. parabolicus. In the brasilianus group, $B$. affinis with four variations and $B$. scutatus with seven variations are presented, and five new species are described. New records from Brazil are provided for B. affinis and B. scutatus. In the giganteus group, $B$. giganteus is presented. A new group (macurus) with one new species is described.

\section{Material and Methods}

The specimens were analyzed morphologically according to the usual techniques, as described by Lopes \& Oliveira (2000). The terminology of the genital parts, the basic bibliography, and the taxonomic classification are based on the concepts proposed by Roth (1969, 1970, 1976 and 2003). The phylogenetic position of the genus follows Kambhampati (1995) and Klass \& Meier (2006). After analysis, the plates and the genital parts were placed in microvials containing glycerin and stored with their respective specimens, mounted on insect pins according to the technique developed by Gurney et al. (1964). All material deposited in the collection will be assigned MNRJ catalog numbers. The material can be found in the Blattaria collection of the Museu Nacional.

\section{Results}

\section{1) Atropos Group}

Blaberus amazonensis sp. nov.

General coloration light brown (Figure 1a). Dark-brown head; light yellowish-brown ocellus and clypeus (Figure 1b); brown antennae with 15 shiny basal articles, remaining articles opaque; palpi golden tomentose. Pronotum with black central-basal spot showing three small light yellowish-brown spots in the center; narrow yellowish stripe delimiting apex of black spot (Figure 1c). Tegmina light-colored, with only the basis of the branch of all veins dark brown. Abdominal segments light-colored, with dark spot on each lateral extremity.

Dimensions (mm). Total length: 68; length of pronotum: 14; width of pronotum: 19; length of tegmen: 58; width of tegmen: 20.

Head subtriangular with vertex covered by pronotum; space narrow, measuring about one-sixth of distance between bases of antennal sockets; ocellus large, deflected in relation to the face; antennae long, overreaching base of abdomen.

Thorax. Pronotum elliptical, transverse, with lateral tips slightly deflected and apical surface in relief. Developed legs. Cephalic femur with ventro-cephalic margin bearing three robust spines extending from base to near midlength, followed by dense row of small cilia extending to apex, plus robust apical spine; ventro-caudal margin with sparse cilia and robust apical spine; middle and posterior femurs with ventro-cephalic margin bearing sparse cilia plus robust apical spine; ventro-caudal margin with dense row of cilia extending from base to apex, plus robust apical spine. A genicular spine is present; pulvilli on all tarsal articles; nails symmetrical and simple; arolia absent. Tegmen with narrow marginal field, deflected and long, overreaching middle of tegmen; narrow scapular field with longitudinal venule arrangement; discoidal field large, with obliquely laid veins; anal field ample. Developed wings, small apical triangle; anal field folded fanlike.

Abdomen. Supra-anal and subgenital plates typical of the genus. Left phallomere in form of two laminas, one of which is more acute, and both touching the apex (Figure 1d); median sclerite little developed, with rounded apex; prepuce with row of small spines extending from base to next to apex (Figure 1e); right phallomere elongated and hook-shaped with a discrete pre-apical indentation; internal sclerotized structure present (Figure 1f).

Material examined: Holotype $\widehat{\partial}$, Brazil, Amazonas, Estirão do Equador (Rio Javari), (MNRJ).

Etymology: The species was named after the state in which it was collected.

Blaberus atropos (Stoll, 1813)

Blatta atropos Stoll, 1813: 4; 

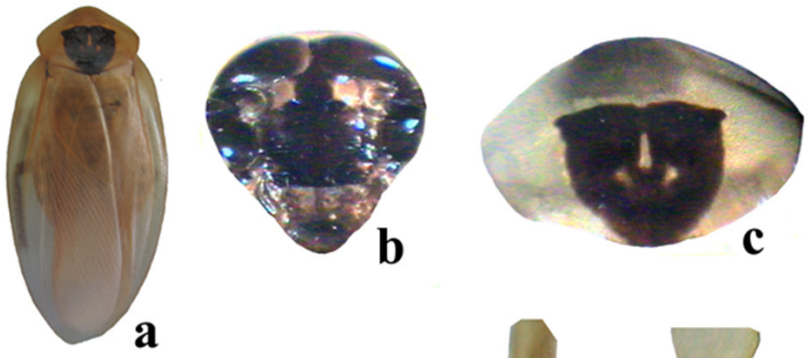

a
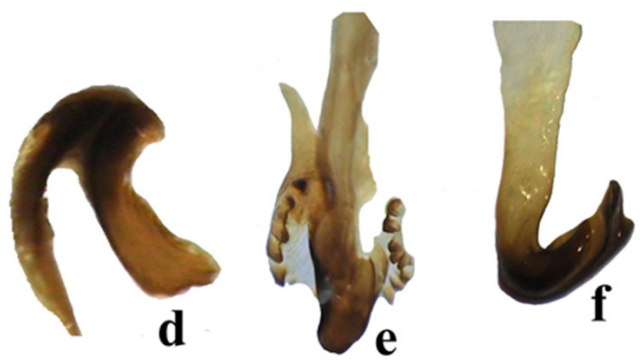

Figure 1. Atropos group, sensu Roth. B. amazonensis. a. habitus (66 mm); b. head, ventral $(7 \mathrm{~mm})$; c. pronotum, dorsal $(19 \mathrm{~mm})$; d. left phallomere, dorsal $(2 \mathrm{~mm})$; e. median sclerite, dorsal (3 mm); f. right phallomere, dorsal (3 mm).

Blabera fusca Brunner de Wattenwyl, 1865: 376; Princis, 1963: 127, 131; Beccaloni, 2012. http://blattodea.speciesfile.org

Blabera laticollis Walker, F. 1868: 5; Princis, 1963: 131; Beccaloni, 2012. http://blattodea.speciesfile.org

Blabera atropos Brunner de Wattenwyl, 1865: 375-376

Blaberus atropos Bruijning, 1959: 3, 6-7; Princis, 1963: 131; Rocha \& Silva-Albuquerque, 1964: 5; Vanschuytbroeck, 1969: 5; Roth, 1969: 220-221, 234, 242; Rocha \& Silva, 1982: 3; Beccaloni, 2012. http://blattodea.speciesfile.org; Pellens \& Grandcolas, 2008: 43.

The species was well described by Roth (1969). In the collection of Blattaria of the Museu Nacional, six variations whose habituses are shown in Figure 2(a-f) were analyzed, as well as the individuals collected in northern Brazil, in the states of Amazonas, Pará and Rondônia. The coloration of the head may vary from dark brown to black with the ocellus varying from yellow to rose, but always distinct. The clypeus is slightly or very evident (Figure 3a-f). The pronotum is slightly tapered apically and has a dark-brown quadrangular spot with slight nuances of light brown (Figure 4a-f). In the genitalia, the median sclerite (Figure 5a-f) always shows the prepuce bordered with a row of spines, which on the left are more developed, denser and more sclerotized, forming a crest; in the right side with one additional row of spines; the prepuce involves the apex of the median sclerite, which is more sclerotized; the right hook-like phallomere more developed, with the apex more acute and distinct and having a pre-apical incision (Figure 6a-e); and the left phallomere is in the shape of two acute laminas that unite dorsally (Figure 6f-k).

Material examined: Brazil: 1 रิ Rondônia; $2 \hat{\gamma}$ and 2 ㅇ

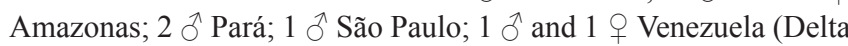
Amacuro); 1 ठ̊ Colombia.

Geographical Distribution: São Domingos, Jamaica, Guiana, Suriname, Trinidad, Tobago Bay, Cuba, Mexico, Venezuela, Colombia, Chile, Brazil (Rio de Janeiro, with new records in Amazonas, Pará, Rondônia and São Paulo).

\section{Blaberus colombianus sp. nov.}

General coloration light yellowish-brown and shiny (Figure 7a). Head dark brown with lighter ocellus and post-clypeus (Figure 7b); buccal palpi and antennae golden-tomentose. Pronotum with compact dark-brown central basal spot and narrow yellow stripe along apical
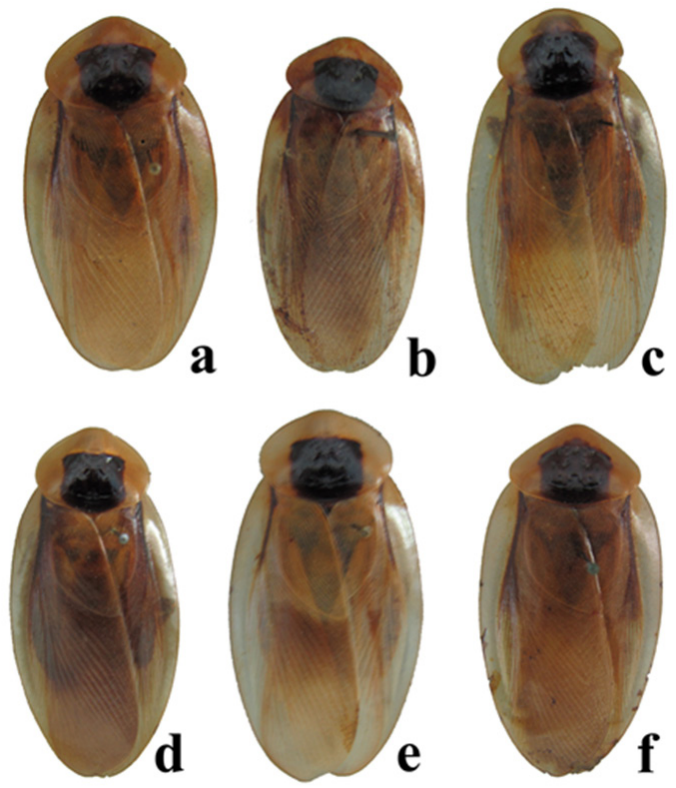

Figure 2. Atropos group: B. atropos, sensu Roth: habitus: Amazonas: a. (55 mm); Rondônia: b. (58 mm), c. (66 mm), e. (69 mm); Pará: d. (70 mm), f. $(55 \mathrm{~mm})$.
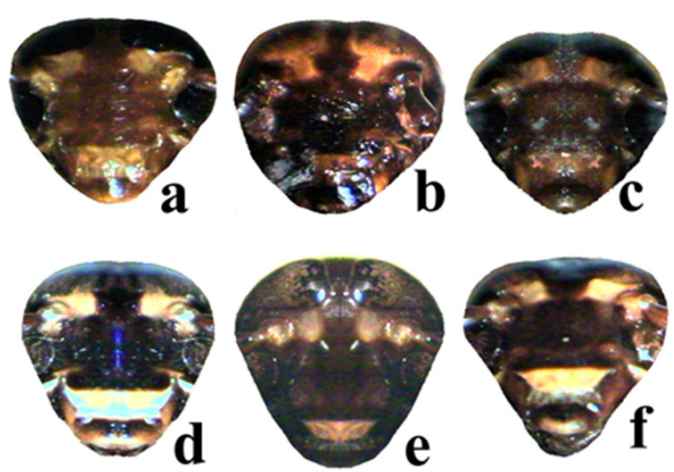

Figure 3. Atropos group: B. atropos, sensu Roth: head, ventral (6 mm): Amazonas: a; Rondônia: b, c, e. Rondônia; Pará: d, f.
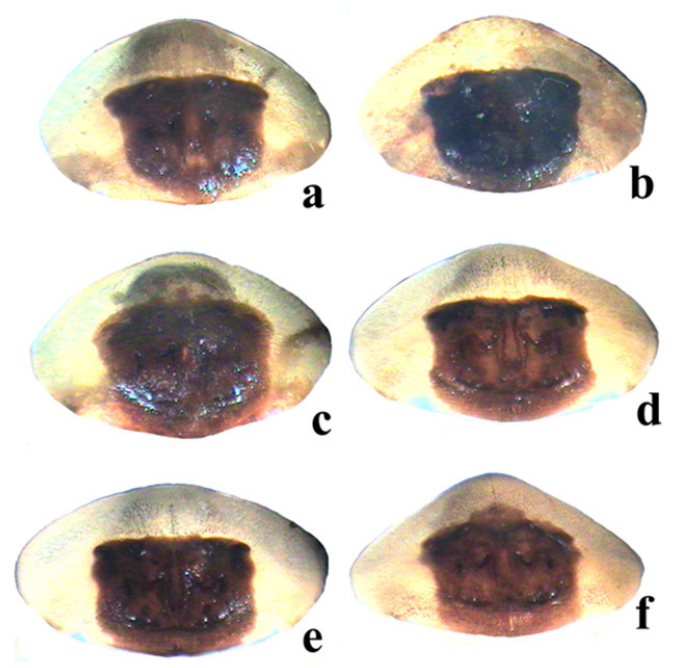

Figure 4. Atropos group. B. atropos, sensu Roth: pronotum, dorsal (19 mm). Amazonas: a; Rondônia: b, c, e; Pará: d, f. 

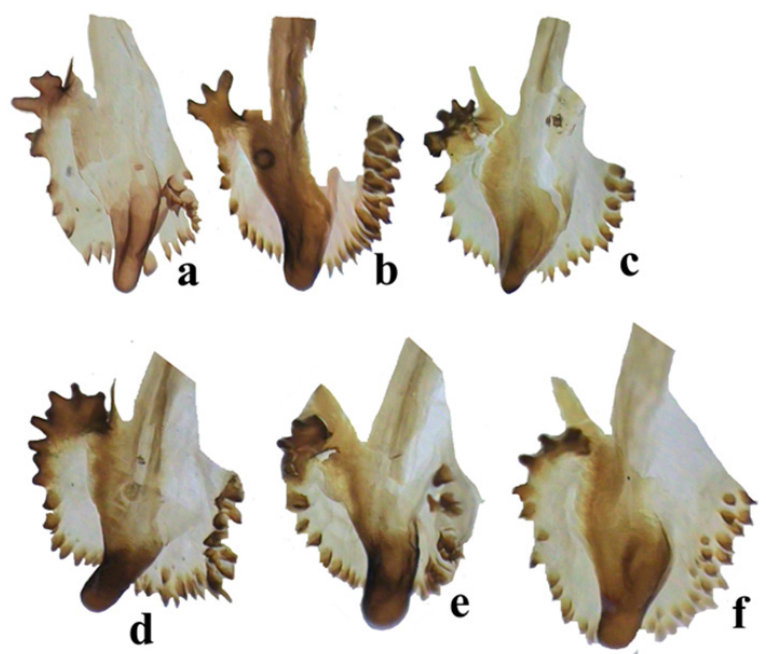

Figure 5. Atropos group. B. atropos: median sclerite apical, dorsal (2 mm). Amazonas: a; Rondônia: b, c, e; Pará: d, f.
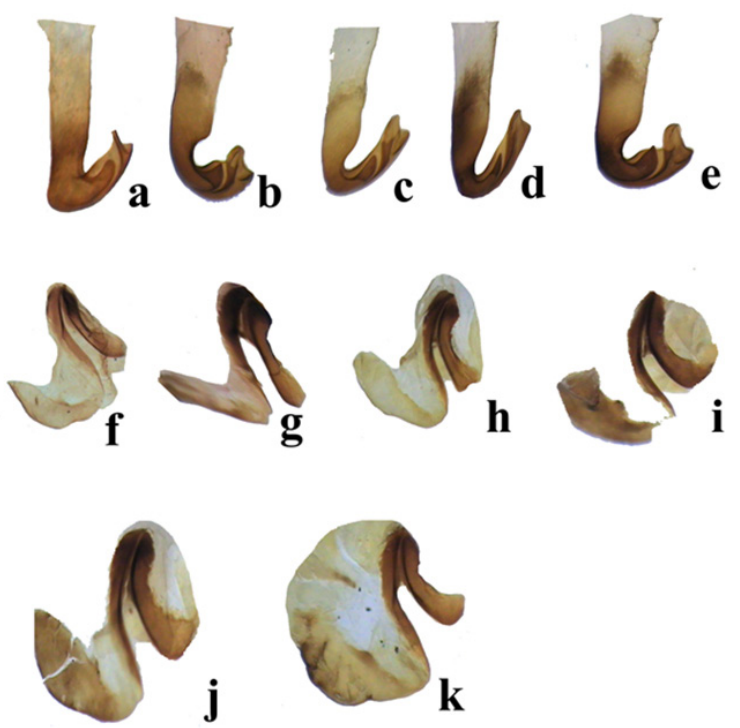

Figure 6. Atropos group. B. atropos, sensu Roth: right phallomere, dorsal (2 mm). Amazonas: a; Rondônia: b, c, e; Pará: d; left phallomere, dorsal (2 mm). Amazonas: f.; Rondônia: g, h, j; Pará: i, k.; right phallomere, dorsal ( $2 \mathrm{~mm}$ ). Amazonas: a.; Rondônia: b, c, e. Pará: d; left phallomere, dorsal (2 mm). Amazonas; f.; Rondônia: g, h, j; Pará: i, k.

border (Figure 7c). Tegmen light, with initial branch of all dark-brown veins radiating to base of discoidal field. Legs with yellow pulvilli.

Head subtriangular with rounded apical border, vertex totally covered by pronotum in dorsal view; interocular space narrow, measuring about one-fourth distance between bases of antennal sockets; ocellus large and rounded; antennae overreaching first segments of abdomen; maxillar palpi with third article larger than the others, fourth and fifth articles dilated at apex.

Thorax with pronotum elliptical, transverse with slight convexity, median-apical surface slightly salient and in relief. Robust legs, cephalic femur with ventro-cephalic margin with three robust spines extending to midlength, followed by dense row of ciliform spines extending to apex plus robust apical spine; ventro-caudal margin with sparse cilia and robust apical spine. Middle and posterior femurs, ventro-cephalic margin with five ciliform, spaced spines

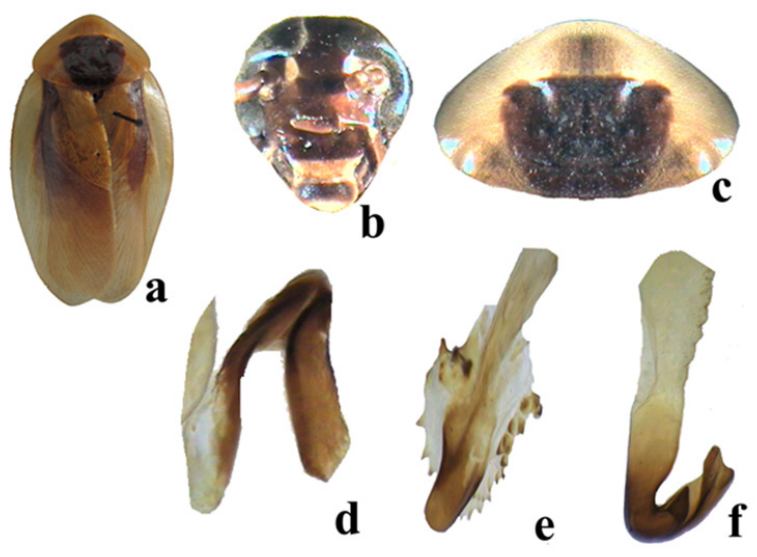

Figure 7. Atropos group, sensu Roth. B. colombianus: a. habitus (19 mm); b. head, ventral $(6 \mathrm{~mm})$; c. pronotum, dorsal $(17 \mathrm{~mm})$; d. left phallomere, dorsal $(2 \mathrm{~mm})$; e. apical median sclerite, dorsal $(2 \mathrm{~mm})$; f. right phallomere, dorsal $(2.5 \mathrm{~mm})$.

plus robust apical spine; ventro-caudal margin with dense row of ciliform spines extending from base to apex, plus robust apical spine on middle femur only; genicular spine present. Long and lanceolate tegmina overreaching apex of cerci; narrow and deflected marginal field; elongated scapular field; discoidal field ample, with obliquely laid veins. Developed wings, small triangular apical and anal field folded fanlike.

Abdomen. Supra-anal and subgenital plates typical of the genus. Left phallomere in the shape of two laminas which unite at the apex (Figure 7d). Elongated, hook-like right phallomere with pre-apical indentation, apex developed with salient extremity; sclerotized internal structure (Figure 7f). Median sclerite with rounded and developed apex; prepuce with crown of four spines on left side and row of small spines extending along entire border (Figure 7e).

Dimensions (mm): Total length: 51; length of pronotum: 12; width of pronotum: 18; length of tegmen: 43; width of tegmen: 15 .

Material examined: Holotype $\hat{\delta}$, Colombia, VII/1914, Bruce Martin col.

Comment: Similar to B. boliviensis Princis, 1946 in the general coloration, but the configuration of the median sclerite distinguishes it from the former species.

Etymology: The species was named after the country where it was collected.

Blaberus duckei Jurberg, Albuquerque, Rebordões, Goncalves \& Felippe, 1977

B. duckei Jurberg, Albuquerque, Rebordões, Gonçalves \& Felippe, 1977: 539-555; Lopes \& Oliveira, 2000: 3; Beccaloni, 2012. http://blattodea.speciesfile.org; Pellens \& Grandcolas, 2008: 43.

Jurberg et al. (1977) characterized the species as being similar to B. parabolicus Walker, 1868 and B. peruvianus Jurberg, Albuquerque, Rebordões, Gonçalves \& Felippe, 1977, differing in "morphological details of the genitalia of the male and the female individuals". In this study, the habitus (Figure 8a), head (Figure 8b), pronotum (Figure 8c), and structures of the genitalia of the male including the left phallomere (Figure 8d), median sclerite (Figure 8e) and right phallomere (Figure 8f) are described.

Material examined: Holotype $\widehat{\delta}$ and allotype + , Brazil, Amazonas, Manaus, Reserva Ducke (MNRJ).

Geographical distribution: Brazil (Amazonas). 

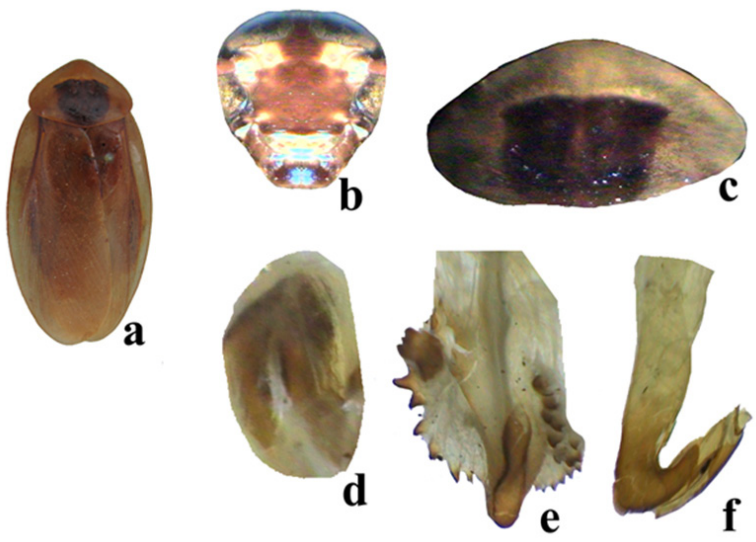

Figure 8. Atropos group, sensu Roth. B. duckei: a. habitus (55 mm); b. head, ventral $(6 \mathrm{~mm})$; c. pronotum, dorsal $(19 \mathrm{~mm})$; d. left phallomere, dorsal $(1.5 \mathrm{~mm})$; e. apical median sclerite, dorsal $(2 \mathrm{~mm})$; f. right phallomere, dorsal $(2 \mathrm{~mm})$.

\section{Blaberus parabolicus Walker, 1868}

Blabera aequatoriana Bolívar, 1881: 479; Princis, 1963:130; Beccaloni, 2012: http://blattodea.speciesfile.org

Blabera armigera Scudder, 1869 : 343; Princis, 1963: 130; Beccaloni, 2012: http://blattodea.speciesfile.org

B. parabolicus Walker, 1868: 8; Kirby, 1904: 164; Rehn, 1916: 234; Hebard, 1921: 149; Campos, 1926: 56; Hebard, 1929: 380; Rehn, 1933: 58; Princis, 1946: 145; Princis, 1958: 74; Bruijning, 1959: 8; Leféuvre, 1960: 147; Princis, 1963: 129; Rocha e Silva-Albuquerque, 1964: 5; Vanschuytbroeck, 1969: 5; Roth, 1969: 220-221, 234, 242; 1970: 313; Rocha \& Silva-Albuquerque, 1972: 3; Rocha, Silva \& Aguiar, 1977: 5; Jurberg et al., 1977: 547; Beccaloni, 2012: http:// blattodea.speciesfile.org; Pellens \& Grandcolas, 2008: 44.

Six variations, of which the habituses are represented in Figure 9a-f, were analyzed. Head black to dark brown, with white to yellow ocellus (Figure 10a-f). The pronotum has black to dark-brown coloration on the central disc, with small median lighter nuances (Figure $10 \mathrm{~g}-1$ ). In the genitalia, the median sclerites do not show great variations and are shown in Figure $11 \mathrm{a}-\mathrm{f}$, the right phallomere is hook-shaped with a marked pre-apical incision (Figure 11g-1) and the left phallomere is in the shape of two laminas (Figure 11m-r).

Material examined: Brazil, 5 Amazonas; 1 q Goiás; 2 São Paulo; 2 q Pará; $2 \hat{\delta}$ and 1 q Mato Grosso; 3 q Rondônia.

Geographical distribution: Bolivia, Colombia, Equador, Guiana, Suriname, Peru, Brazil (Amazonas, Pará, Mato Grosso, with new records for Rondônia, Goiás, São Paulo).

\section{Blaberus matogrossensis Rocha e Silva \& Aguiar, 1977}

B. matogrossensis Rocha e Silva \& Aguiar, 1977: 3; Lopes \& Oliveira, 2000: 4; Beccaloni, 2012: http://blattodea.speciesfile.org; Pellens \& Grandcolas, 2008: 44.

Drawing on the habitus (Figure 12a), the authors described the species as similar to B. parabolicus Walker, 1868 differing in the morphology of the structures of the genitalia of the male, particularly the median sclerite. The male holotype and the female allotype have been analyzed here (Figure 12b). The pronotum has a black spot with three light median spots on the central disc (Figure 12c). The median sclerite bears a crest next to the base of the apex and a row of small spines on the left side; the right side of the prepuce bears a crest on the base, followed by a row of simple spines (Figure 12d). The right phallomere is hook-shaped with a slight pre-apical incision; very developed apex ending in a straight shape (Figure 12e). The left phallomere was not found.
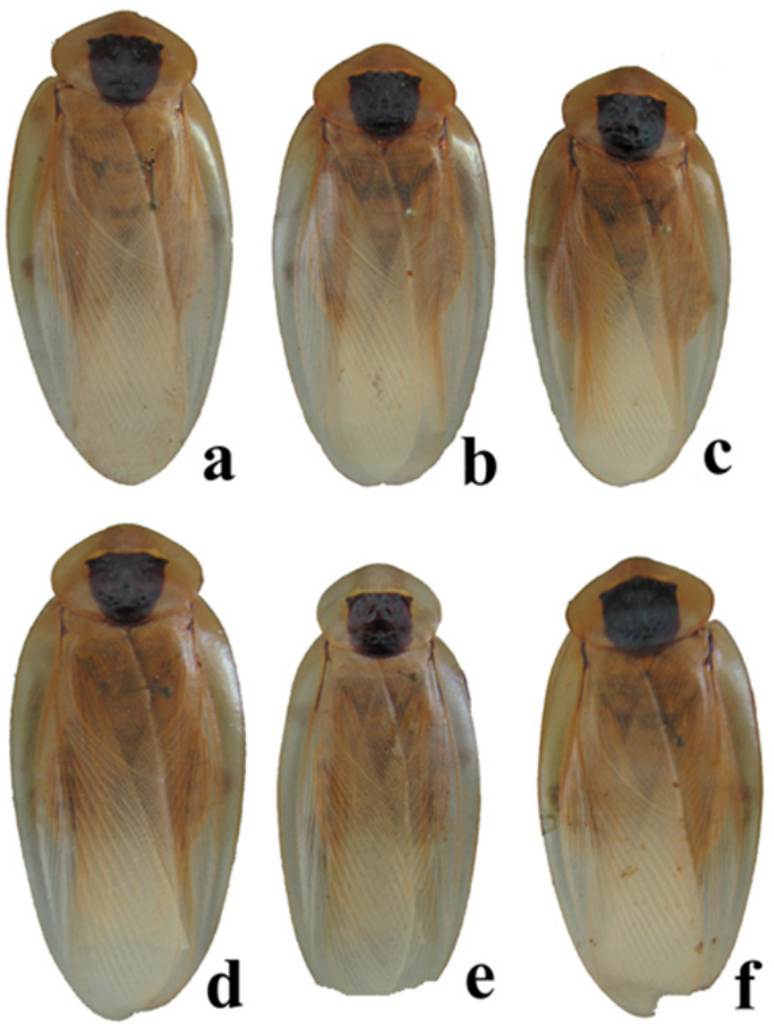

Figure 9. Atropos group, sensu Roth. B. parabolicus: habitus: Amazonas: a. $(70 \mathrm{~mm})$, b. (66 mm), c. $(65 \mathrm{~mm})$, d. $(65 \mathrm{~mm})$, f. (64 mm); Rondônia: e. (64 mm).
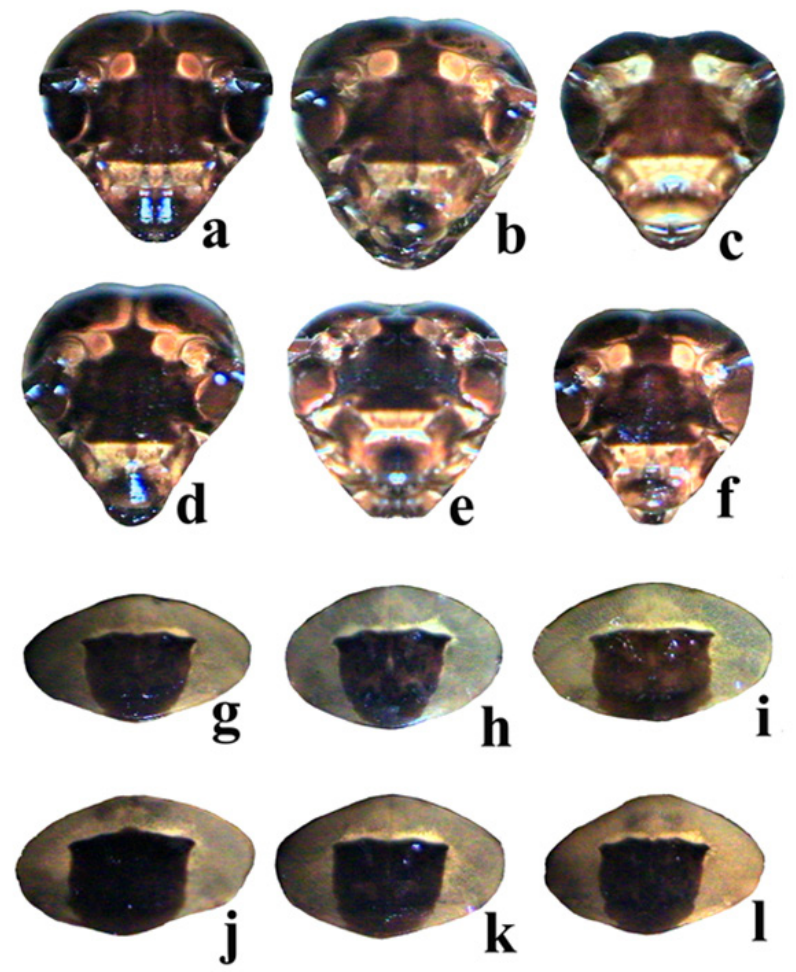

Figure 10. Atropos group, sensu Roth. B. parabolicus: head, ventral (6 mm): Amazonas: a, b, c, d, f.; Rondônia: e. Pronotum, dorsal (18 mm): Amazonas: g, h, i, j, l.; Rondônia: k. 

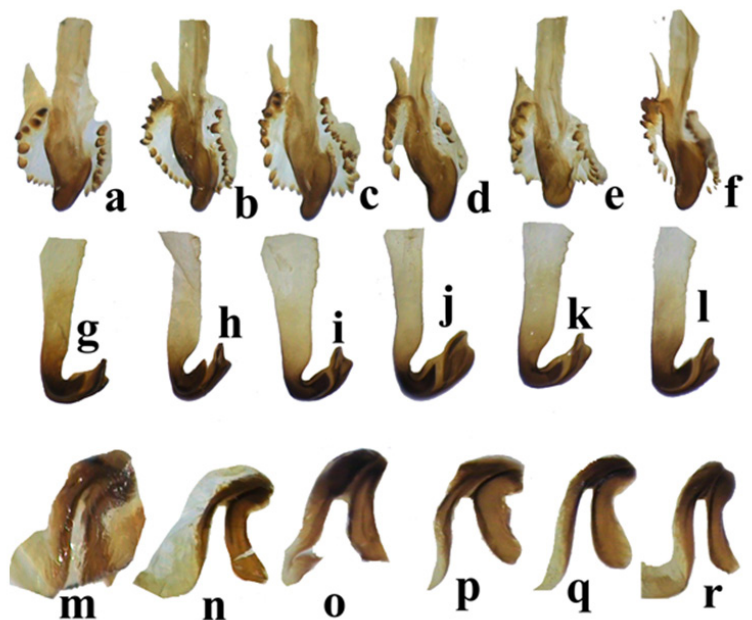

Figure 11. Atropos group, sensu Roth. B. parabolicus: median sclerite, dorsal (2 mm): Amazonas: a, b, c, d, f.; Rondônia: e; right phallomere, dorsal (2 mm): Amazonas: g, h, i, j, l; Rondônia: k; left phallomere, dorsal (2 mm). Amazonas: m, n, o, p, s.; Rondônia: r.
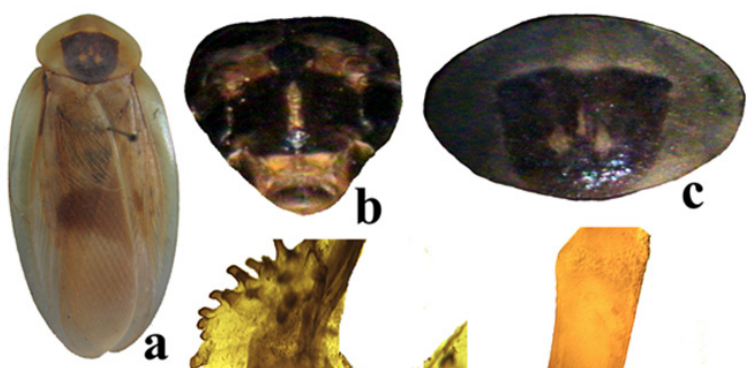

a
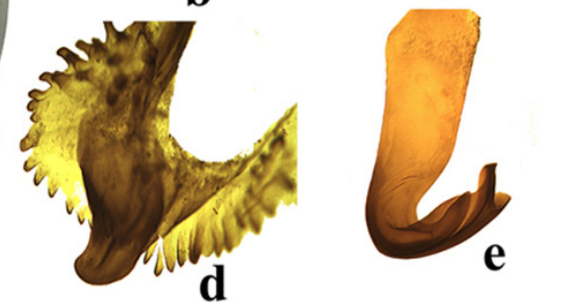

Figure 12. Atropos group, sensu Roth. B. matogrossensis. a. habitus; b. head, ventral (7 mm); c. pronotum, dorsal (19 mm); d. median sclerite, dorsal (2 mm); e. right phallomere, dorsal (2 mm).

Material examined: 1 $\precsim$ Holotype and 1 A Allotype, Brazil, Mato Grosso, Sinop, X/1975, Alvarenga \& Roppa col..

Geographical distribution: Brazil (Mato Grosso).

Comment: The species resembles B. parabolicus Walker, 1868, differing in the configuration of the right phallomere and the spines on the prepuce.

\section{Blaberus neomatogrossensis sp. nov.}

General Coloration. Shiny, light yellowish-brown (Figure 13a). Dark-brown head; lighter brown around eyes, ocellus and postclypeus (Figure 13b), dark buccal palpi and antennae goldentomentose. Pronotum with dark-brown center-basal spot with small irregular areas that are lighter medially (Figure 13c). Tegmen light, with dark-brown initial branch of all veins and a transverse median brown stripe. Brown legs with whitish-brown pulvilli; brown abdominal sternites with yellowish basal stripe, with brown spot in low relief next to lateral extremities.

Head subtriangular, rounded lateral-apically; vertex covered by pronotum in dorsal view; interocular space narrow, measuring about one-fifth of distance between bases of antennal sockets, ocellus large and rounded; antennae long, overreaching first segments of abdomen;
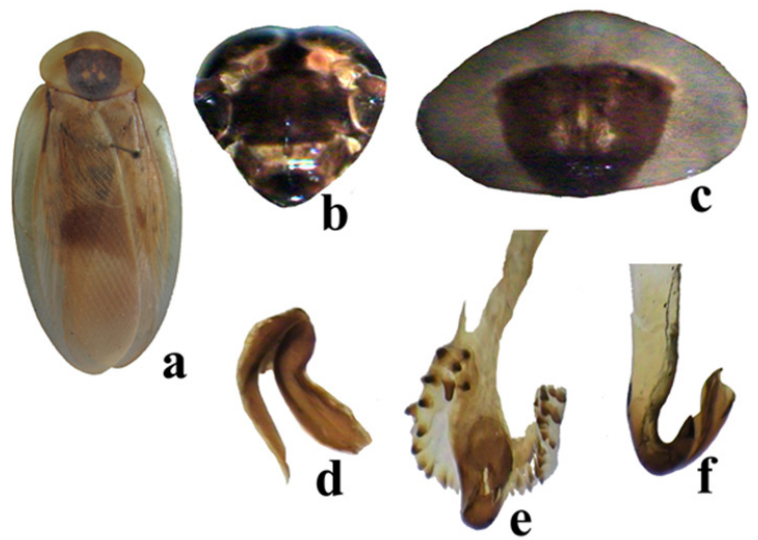

Figure 13. Atropos group, sensu Roth. B. neomatogrossensis. a. habitus (66 mm); b. head, ventral $(7 \mathrm{~mm})$; c. pronotum, dorsal $(19 \mathrm{~mm})$; d. left phallomere, dorsal (2 mm); e. median sclerite, dorsal (2 mm); f. right phallomere, dorsal (2 $\mathrm{mm})$.

developed and slightly salient post-clypeus; maxillar palpi with third article largest; fourth and fifth articles with dilated apex.

Dimensions (mm). Total length: 66.0; length of pronotum: 13.0; width of pronotum: 19.0; length of tegmen: 56.0; width of tegmen: 20.0 .

Thorax. Elliptical, transverse pronotum with slight convexity, median-apical region with a slight salient surface and in relief. Legs robust and developed, anterior femur with ventro-cephalic margin bearing three robust spines extending to midlength, followed by row of ciliform spines extending to apex which bears a robust spine. Ventro-caudal margin with sparse cilia and robust apical spine. Middle and posterior femurs with ventro-cephalic margin with four to six ciliform spines set at intervals plus robust apical and ventrocaudal margin with a dense row of ciliform spines extending from base to apex, plus robust apical spine. Genicular spine present on the middle and posterior femurs. Developed pulvilli throughout the tarsal articles; symmetrical and simple nails; arolia absent. Long, lanceolated tegmina overreaching apex of cerci; narrow and deflected marginal field; elongated scapular field; ample discoidal field with longitudinally laid veins. Developed wings, small apical triangle and ample anal field folded fanlike.

Abdomen. Supra-anal and subgenital plates typical of the genus. Left phallomere shaped as two laminas, one of which is very acute (Figure 13d); median sclerite little developed,; prepuce with row of spines bearing a crest with six sclerotized spines followed by eight smaller spines which are aligned and slightly rounded, and on right side a smaller crest with small spines (Figure 13e); right phallomere long and hook-like with marked pre-apical indentation and flammuliform apex (Figure 13f); sclerotized internal structure.

Material examined: Holotype $\widehat{\partial}$, Brazil, Mato Grosso, Sinop, $12^{\circ}$ $31^{\prime} \mathrm{S}, 55^{\circ} 37^{\prime} \mathrm{W}, \mathrm{BR} 163 \mathrm{~km}, 350 \mathrm{~m}$ alt.; 2 Paratypes ${ }^{\top}$, Venezuela, Guárico, S. Juan de Los Morros, Cueva los Morritos.

Etymology: The name of the species derives from its similarity to B. matogrossensis Rocha e Silva \& Aguiar, 1977.

\section{Blaberus paulistanus Lopes \& Oliveira, 2000}

B. paulistanus Lopes \& Oliveira, 2000: 1-4; Beccaloni, 2012: http://blattodea.speciesfile.org; Pellens \& Grandcolas, 2008: 44.

According to the authors, the species described by the habitus (Figure 14a) resembles Blaberus matogrossensis Rocha e Silva $\&$ Aguiar, 1977, differing, however, in the coloration of the head, which is dark brown on the front and grayish-brown on the labrum 


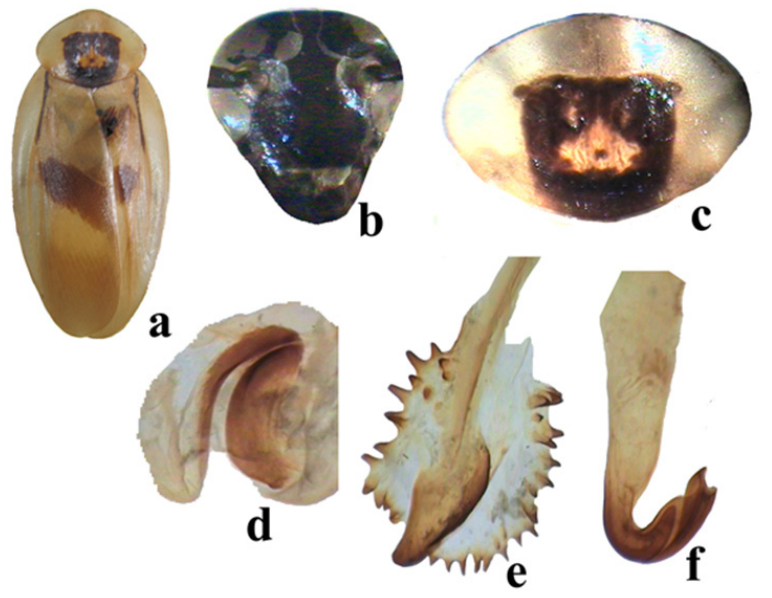

Figure 14. Atropos group, sensu Roth. B. paulistanus: a. habitus; b. head, ventral $(7 \mathrm{~mm})$; c. pronotum, dorsal $(19 \mathrm{~mm})$; d. left phallomere, dorsal (2 mm); e. median sclerite (L2vm), dorsal (3 mm); f. right phallomere, dorsal $(2 \mathrm{~mm})$

(Figure 14b); in the pronotum, which has a large black center-basal trapezoid spot, whose irregular median light yellow (Figure 14c); in the transverse stripe on the left tegmen, which is darker and well defined; and in the details of the male genitalia, including the left phallomere in the form of two laminas, one of which is acute (Figure 14d); the apex of the median sclerite has a slight sinuosity with no abrupt medial sharpening and the apex is straight and acuminate, not widened; the prepuce has evenly spaced spines on the edges (Figure 14e); and the right phallomere is long and hook-like with a pre-apical indentation and the apex is flammuliform (Figure 14f) with an internal sclerotized structure.

Material examined: Holotype $\widehat{\jmath}$, Brazil, São Paulo.

Blaberus peruvibolicus sp. nov.

General coloration is shiny light brown (Figure 15a). Head dark brown with light yellowish-brown ocellus and clypeus (Figure 15b). Pronotum with central-basal black spot with narrow yellowish stripe just above the spot (Figure 15c). Light tegmina with initial branch of veins dark brown.

Dimensions (mm). Total length: 65 ; length of pronotum: 14 ; width of pronotum: 20; length of tegmen: 55; width of tegmen: 20 .

Subtriangular head; vertex covered by pronotum; large and slightly projected eyes; interocular space narrow, measuring about one-fourth of distance between bases of antennal sockets; wellmarked ocellus; median antennae overreaching base of abdomen.

Thorax. Elliptical, transverse pronotum with ample lateral edges that are slightly deflected; slightly salient apical surface. Legs with cephalic femur showing ventro-cephalic margin with three small but robust spines on basal third, followed by row of small spines extensing to apex plus robust apical spine; ventro-caudal margin with sparse cilia plus one robust apical spine, middle and posterior femurs with sparse cilia plus one robust apical spine; genicular spines present on middle and posterior femurs; pulvilli on all tarsal articles; arolia absent; nails simple and symmetrical. Tegmen with narrow, long and deflected marginal field overreaching tegmen; narrow scapular field with oblique venule arrangement; discoidal field ample, with longitudinally laid veins; ample anal field with 11 or more axillary veins. Developed wings, small apical triangle and anal field folded fanlike.

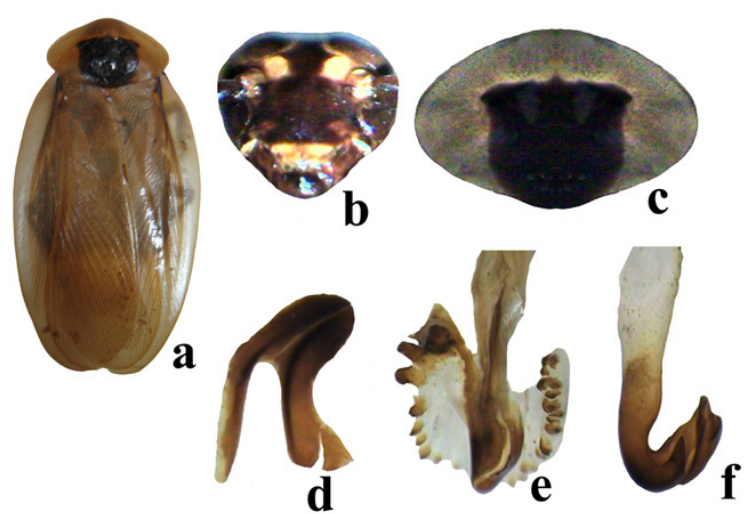

Figure 15. Atropos group, sensu Roth. B. peruvibolicus. (Mato Grosso). a. habitus $(65 \mathrm{~mm})$; b. head, ventral $(7 \mathrm{~mm})$; c. pronotum, dorsal $(20 \mathrm{~mm})$; d. left phallomere, dorsal ( $2 \mathrm{~mm})$; e. median sclerite, dorsal (3 mm); f. right phallomere, dorsal (2 $\mathrm{mm})$.

Abdomen. Supra-anal and subgenital plates typical of the genus. Left phallomere has the shape of two laminas (Figure 15d); median sclerite widen at base, narrowing toward apex; prepuce with row of spines bearing crest with three robust spines on left side at base, followed by six smaller aligned spines (Figure 15e); right phallomere hook-shaped, with marked pre-apical indentation; and apical projection that is more acute, developed and straight (Figure 15f). Sclerotized internal structure.

Material examined: Holotype $\widehat{\partial}$, Brazil, Mato Grosso, Sinop, IX/1976. O. Roppa col.; 1 Paratype $\widehat{\jmath}$, similar data as for holotype; 1 Paratype $\widehat{o}$, Brazil, Amazonas, Manaus, III/1933, no collector named.

Etymology: The name of the species derives from its similarity to $B$. peruvianus Jurberg, Albuquerque, Rebordões, Gonçalves \& Felippe, 1977

\section{Blaberus yuracianus sp. nov.}

Shiny, light yellowish-brown general coloration (Figure 16a). Head dark brown, ocellus and apex of the clypeus yellowish (Figure 16b); brown antennae and palpi golden-tomentose. Pronotum with dark-brown central basal spot with darker details in low relief, with yellow outline on the anterior margin (Figure 16c). Light tegmen with initial branch almost black and medially with indistinct transverse spot. Legs brown, with ventral-basal surfaces of the thighs; yellowish pulvilli. Abdomen brown, with sternites bearing yellowish central-lateral and lateral-apical spots.

Dimensions (mm). Total length: 62.0; length of pronotum: 13.0; width of pronotum: 19.0; length of tegmen: 53.0; width of tegmen: 19.0.

Head subtriangular with roundish apical outline; large eyes; narrow interocular space measuring about one-fifth of distance between bases of antennal sockets; large ocellus; vertex covered by pronotum in dorsal view; antennae long, overreaching first segments of abdomen. Developed and slightly salient post-clypeus; maxillar palpi with third article slightly larger than fourth, and fifth article dilated and tomentose.

Thorax. Elliptical, transverse pronotum with slight convexity having median apical surface slightly salient in relief. Robust and developed legs, cephalic femur with ventro-cephalic margin bearing three robust spines extending to middle, followed by dense row of ciliform spines extending to apex which bears a robust spine; ventrocaudal margin with sparse cilia and one robust apical spine; middle and posterior femur, ventro-cephalic margin with sparse cilia plus 


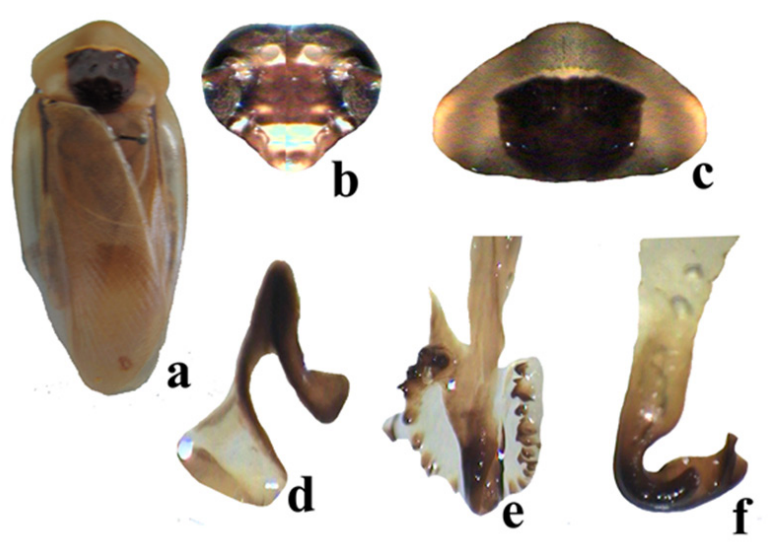

Figure 16. Atropos group, sensu Roth. B. yuracianus. a. habitus (62 mm); b. head, ventral $(7 \mathrm{~mm})$; c. pronotum, dorsal $(19 \mathrm{~mm})$; d. left phallomere, dorsal (2 mm); e. median sclerite, dorsal (3 mm); f. right phallomere, dorsal (2 mm).

one robust apical spine and ventro-caudal margin with dense row of ciliform cilia extending from base to apex, plus one robust apical spine. Robust genicular spine present on the last femurs mentioned. Pulvilli developed on all tarsal articles; nails simple and symmetrical, arolia absent. Long, lanceolate tegmen overreaching apex of cerci; narrow and deflected marginal field; elongated scapular field; discoidal field with longitudinal venule arrangement; anal field ample and well marked. Developed wings, small apical triangle and ample anal field folded fanlike.

Abdomen. Supra-anal and subgenital plates typical of the genus. Left phallomere in shape of two laminas, one of them more acute (Figure 16d); median sclerite with row of five rounded spines which are sparse on left side, followed by sclerotized crest (Figure 16e); right phallomere long and hook-like with marked pre-apical indentation followed by dilation on inner margin; apex with quadrangular projection (Figure 16f). Apical formation with sclerotized internal structure.

Material examined: Holotype $\hat{\jmath}$, Peru, Yurac, $107.82 \mathrm{~km}$ east of Tingo Maria, 11/XII/1954, E. I. Schlinger \& E. S. Ross cols.

Etymology: The species was named for the locality of collection.

\section{2) Brasilianus Group}

Blaberus affinis Jurberg, R.S. Albuquerque, Rebordões, Goncalves \& Felippe, 1977

B. affinis Jurberg, R.S. Albuquerque, Rebordões, Gonçalves \& Felippe, 1977: 539-540; Lopes \& Oliveira, 2000: 3; Beccaloni, 2012. http://blattodea.speciesfile.org; Pellens \& Grandcolas, 2008: 49.

The male holotype and two variations (Figure 17a-c) were analyzed. According to Jurberg et al. (1977) B. affinis is similar to B. minor Saussure, 1864 and is easily differentiated from the latter by the coloration of the pronotum (Figure 18e-h) which has a large black median spot and yellow front and lateral margins. The coloration may show some variations on the head (Figure 18a-d) and pronotum (Figure 18e-h). The head has dark-brown to black coloration (Figure 18a-d), and on the male genitalia the left phallomere is formed as two acute sclerotized plates (Figure 18i-1); the right phallomere is hook-shaped with a pre-apical incision and the apex more elongated and apically straight or not (Figure $18 \mathrm{~m}-\mathrm{p}$ ), and the median sclerite having a tapered and sclerotized apex, exceeding the formation of the prepuce which lies to the left and to the right with small but distinct sclerotized spines and other minute spines surrounding it
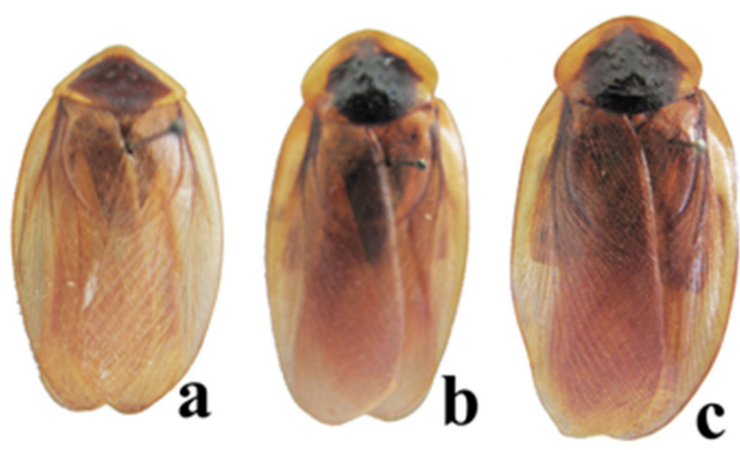

Figure 17. Brasilianus group. B. affinis. Habitus: a. São Paulo (Holotype) (46 mm); b. Goiás (53 mm); c. Rio de Janeiro (49 mm).

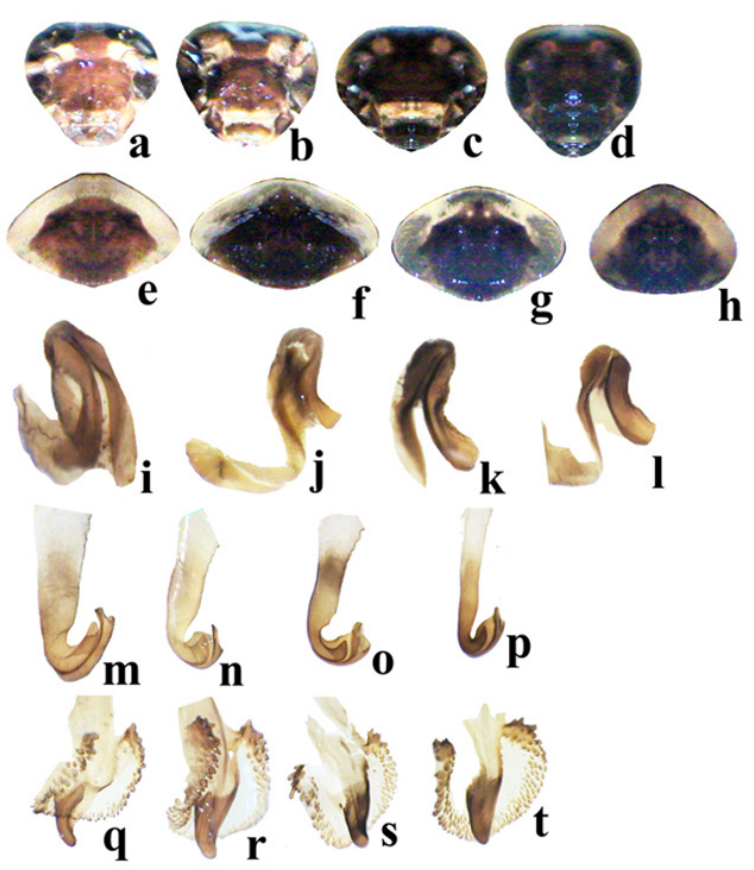

Figure 18. Brasilianus group. B. affinis. head, ventral (6 mm). a. São Paulo (type); b, c, d. Goiás; pronotum, dorsal (16 mm). e. São Paulo (type); f, g, h. Goiás; left phallomere, dorsal (2 mm). i. São Paulo (type); j, k, 1. Goiás; right phallomere, dorsal (2 mm). m. São Paulo (type); n, o, p. Goiás; median sclerite, dorsal (2 mm). q. São Paulo (type); r, s, t. Goiás.

(Figure 18q-t). The right phallomere and the median sclerite of only one of specimens from Goiás State are shown, since they are identical. The female specimens are not shown, due to the absence of any character which differentiates them.

Material examined: Brazil: 1 đै and 1 q, Rio de Janeiro (Paraíba do Sul); 4 \& Mato Grosso; 4 $\widehat{o}$ Goiás; 3 q São Paulo.

New occurrences: Brazil (Mato Grosso, Goiás, São Paulo).

Blaberus chacoensis sp. nov.

General coloration grayish-brown (Figure 19a). Black head with yellowish-white ocellar spots and post-clypeus (Figure 19b); palpi dark, antennae golden-tomentose. Pronotum brown with central basal back spot with three smaller yellowish spots in the median region; lateral edges light-colored, with two round brown spots (Figure 19c). Dark-brown legs with lighter trochanter and inner thighs goldentomentose; yellowish pulvilli. Tegmina with dark-brown initial stem of veins, lighter marginal field. 
Dimensions (mm). Holotype 0 : Total length 41; length of pronotum: 9; width of pronotum: 14; length of tegmen: 35 ; width of tegmen: 13.

Head subtriangular with roundish apex; interocular space wide, measuring half distance between bases of antennal sockets; developed ocelli. Maxillar palpi with dilated apical article, larger than other articles.

Thorax. Elliptical, transverse pronotum convex with lateral edges slightly deflected; antero-apical surface in relief. Legs: fore femur on ventro-cephalic margin having three robust spines extending to midlength, followed by dense row of small cilia extending to apex, plus robust apical spine; ventro-caudal margin with two robust apical spines. Middle femur with one robust apical spine on each margin; posterior femur with ventro-cephalic margin having spine in apical third plus one apical spine; ventro-caudal margin with robust apical spine. Geniculate spine present. Pulvilli on all tarsal articles; symmetrical and simple nails; arolium absent. Tegmen long, overreaching apex of cerci in length; long marginal field reaching midlength of tegmen; narrow scapular field with longitudinal venule arrangement; discoidal field with veins in oblique radiated pattern; ample anal field. Wings with apices of radial vein stems (costal sector) not dilated; small apical triangle; anal field ample and folded fanlike.

Abdomen. Supra-anal and subgenital plates typical of the genus. Left phallomere shaped as two acute median plates united at base (Figure 19d). Median sclerite wide and sclerotized, narrowing toward apex; developed left prepuce with two rows of spines and crests on both sides (Figure 19e). Right phallomere long and hook-shaped with discrete pre-apical indentation, apex acute, ending in rounded extension (Figure 19f).

Material examined: Holotype $\lambda$, Argentina, Parque Nacional Chaco, $26^{\circ} 48^{\prime} 31$ " S, 59 36' 20" W, 10-13/I/2008, Barbosa L. S. Col.; 2 Paratypes $\hat{\jmath}$, Same collection data as for holotype.

Comment: Species close to B. scutatus Saussure \& Zehntner, 1894 , differing in the coloration of the pronotum and in the configuration of the structures of the genitalia.

Etymology: The name of the species is derived from the collection locality in Chaco National Park.

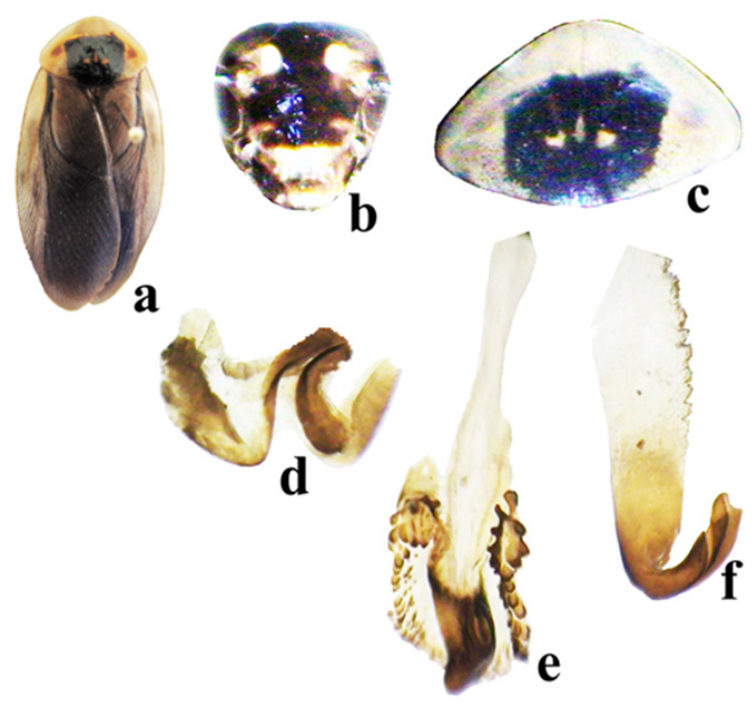

Figure 19. Brasilianus group. Blaberus chacoensis sp. nov.: a. habitus $(40 \mathrm{~mm})$; b. head, ventral $(5 \mathrm{~mm})$; c. pronotum, dorsal $(14 \mathrm{~mm})$; d. left phallomere, dorsal $(2 \mathrm{~mm})$; e. median sclerite, dorsal $(2 \mathrm{~mm})$; f. right phallomere, dorsal $(2 \mathrm{~mm})$
Blaberus neofusiformis sp. nov.

General coloration light brown (Figure 20a-e). Head dark brown; black eyes; brown to yellowish ocellus. Apex of clypeus yellow to light brown (Figure 21a-e); antennae with 14 shiny basal articles, remaining articles opaque. Pronotum with dark-brown central disc with some variations in shape and coloration (Figure 21f-j). Tegmina with dark-brown, almost black initial stem of veins. Parts of abdomen with brown and yellowish areas.

Dimensions (mm). Holotype 0 : Total length: 52; length of pronotum: 11; width of pronotum: 16; length of tegmina: 45; width of tegmina: 16. Paratype 9 . Total length: 54 ; length of pronotum: 12; width of pronotum: 18; length of tegmina: 47; width of tegmina: 17.

Subtriangular head, vertex covered by pronotum; interocular space narrow, measuring about one-fifth of space between bases of antennal sockets. Antennae long, reaching basal third of abdomen.

Thorax. Elliptical, transverse pronotum with deflected lateral edges and sinuous apical surface. Developed legs. Cephalic femur with ventro-cephalic margin bearing three robust spines extending to midlength, followed by dense row of cilia extending to apex, plus one robust apical spine; ventro-caudal margin with sparse cilia plus one robust apical spine. Posterior femur with ventro-caudal margin bearing few small cilia and two robust spines, smaller spine on apical third plus one larger apical spine. Geniculate spine present; pulvilli on four tarsal articles; symmetrical and simple nails; arolia absent. Tegmen long, exceeding apex of cerci in length, long narrow marginal field reaching midlength of tegmen; short narrow scapular field with oblique venule arrangement; ample discoidal field with longitudinal venule arrangement; anal field with eight axillary veins. Wings with small apical triangle and anal field folded fanlike.

Abdomen. Supra-anal and subgenital plates typical of the genus. In genitalia, right phallomere hook-shaped and developed, with pre-
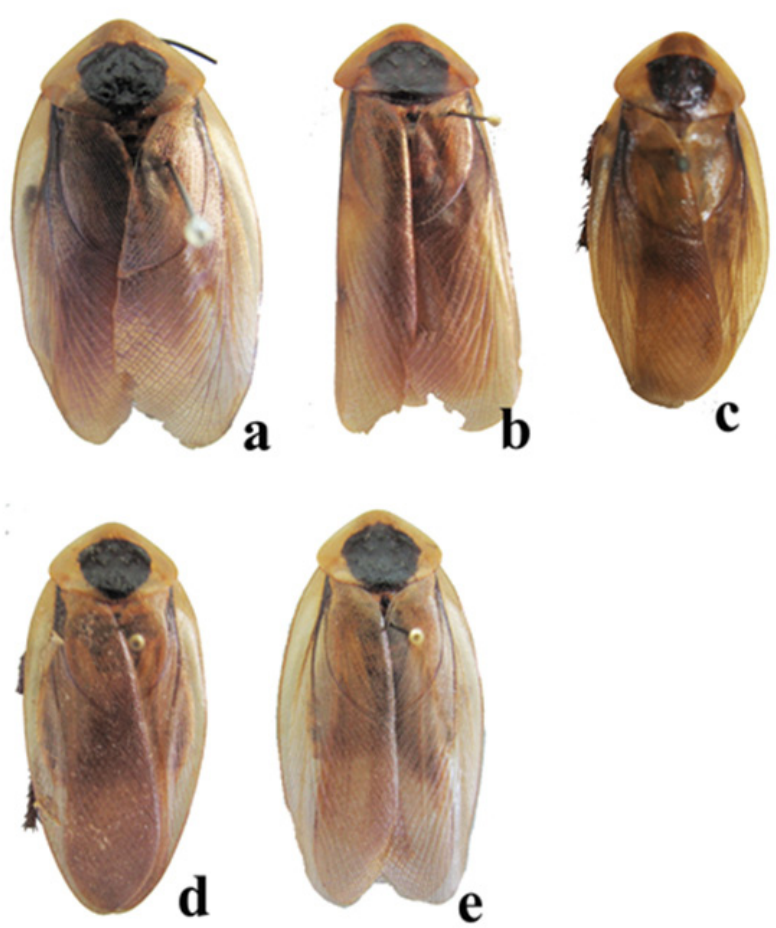

Figure 20. Brasilianus group. Blaberus neofusiformis sp. nov.: Habitus. a. (49 mm), d. (50 mm), e. São Paulo (52 mm); b. Ceará (45 mm); c. Pernambuco (45 mm). 
apical incision and with tapering apex ending in blunt or slightly recurved shape; sclerotized internal structure (Figure 21k-o). Median sclerite with sclerotized apex in shape of tapered and recurved sac; prepuce with three or more rows of spines on left side, basal spines crest-like; on the right side, three rows of spines, slightly larger apically and smaller on median edge toward apex, and with crest of spines next to base of apex of median sclerite (Figure 21p-t). Left phallomere laminate, sclerotized and tapered, joined dorsally (Figure 21u-z).

Material examined. Holotype $\widehat{\jmath}$, Brazil, São Paulo, Severínia, Usina Guarani; 1 Paratype $\widehat{o}$, Brazil, São Paulo, Severínia, Usina Guarani; 1 Paratype $\hat{\jmath}$, Pernambuco (Recife); 2 Paratypes $\hat{\sigma}$, Brazil, São Paulo, Itirapina; Paratype ô, Brazil, Ceará, Chapada do Araripe; Paratype $\hat{\jmath}$, Argentina, Jujuí; Paratype $\hat{\jmath}$, Argentina, Salta, Juramento, Dept. Robles, Santiago del Estero; Paratype ô, Argentina, Salta, Orán; Paratypes $\delta$ and $q$, Argentina, Jujuí, Santa Bárbara Palmar.

Comment: Six specimens representing five variations of each character were analyzed. The species is close to B. fusiformis Walker, 1868 , differing in the coloration of the pronotum, which is also more quadrate and does not reach the base of the pronotum; and in the configuration of all structures of the genitalia.

Etymology. The name of the species derives from its similarity to B. fusiformis.

\section{Blaberus parafusiformis sp. nov.}

Brown coloration in general (Figure 22a, b). Head almost black with reddish-brown ocellus and clypeus varying from yellowishbrown to black (Figure 23a-d); black antennae with first 15 articles shiny and more distal articles opaque and golden tormentose.

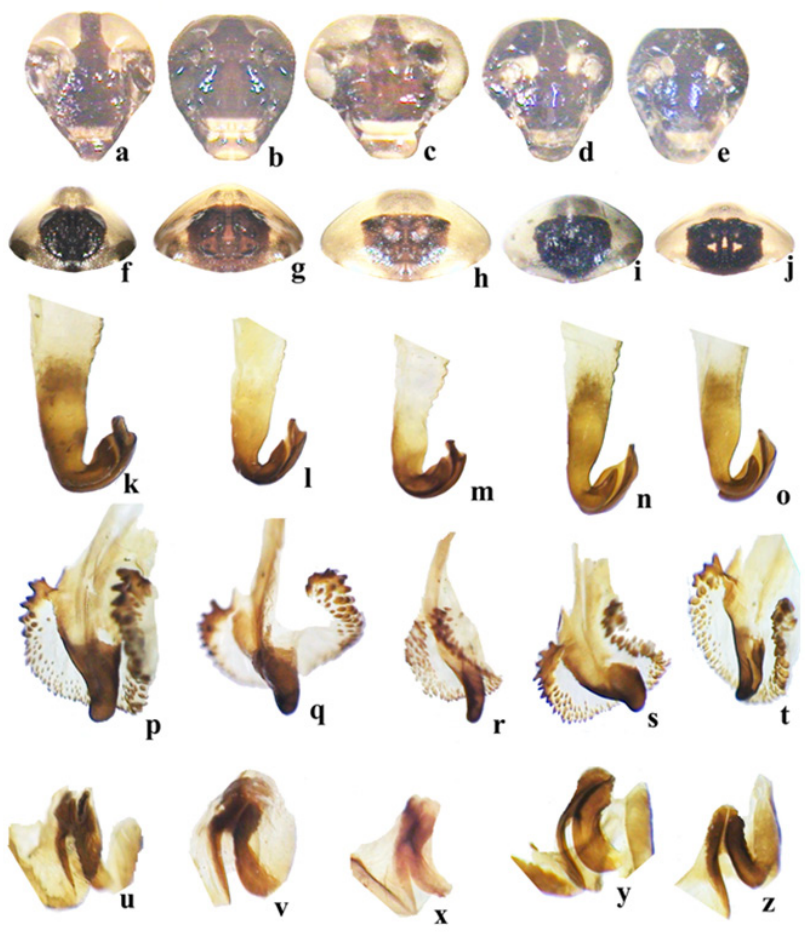

Figure 21. Brasilianus group. Blaberus neofusiformis sp. nov.: head, ventral (5 mm). a, d, e. São Paulo; b. Ceará; c. Pernambuco; pronotum, dorsal (15 mm) f, i, j. São Paulo; g. Ceará; h. Pernambuco; right phallomere, dorsal (2 mm) k, n, o. São Paulo; 1. Ceará; m. Pernambuco; median sclerite, dorsal (2 mm) p, s, t. São Paulo; q. Ceará; r. Pernambuco; left phallomere, dorsal (2 mm) u, y, z. São Paulo; v. Ceará; x. Pernambuco.
Pronotum with blackish-brown spot covering entire central disc and extending to base of pronotum (Figure 23e-h). Tegmina with darkbrown initial stem of veins.

Dimensions (mm). Holotype $\delta$ : Total length: 56; length of pronotum: 11; width of pronotum: 17; length of tegmina: 47; width of tegmina: 18 . Paratype 9 . Total length: 57 ; length of pronotum: 12 ; width of pronotum: 17; length of tegmina: 48; width of tegmina: 18 .

Head subtriangular with rounded apical outline; vertex covered by pronotum; slightly projected eyes; interocular space relatively narrow, measuring about one-third of distance between antennal insertions; maxillar palpi with third and fifth articles larger than others; antennae long, reaching base of abdomen.

Thorax. Elliptical, transverse and convex pronotum with deflected lateral edges. Long legs. Cephalic femur with ventro-cephalic margin with four robust spines extending from base to middle, followed by dense row of cilia extending to apex, plus one robust apical spine; ventro-caudal margin with sparse cilia plus one robust apical spine. Middle femur, ventro-cephalic margin with sparse cilia plus one robust apical spine, and ventro-caudal margin with sparse cilia and sometimes one robust spine on apical third. Posterior femur, ventrocephalic margin with sparse cilia and two robust spines, one on apical third plus one apical; ventro-caudal margin with sparse cilia, lacking apical spine. Geniculate spine present. Pulvilli present on all tarsal articles; nails symmetrical and simple; arolium absent. Developed tegmen narrow, long and deflected marginal field extending to middle of tegmen; short and narrow scapular field; ample discoidal field
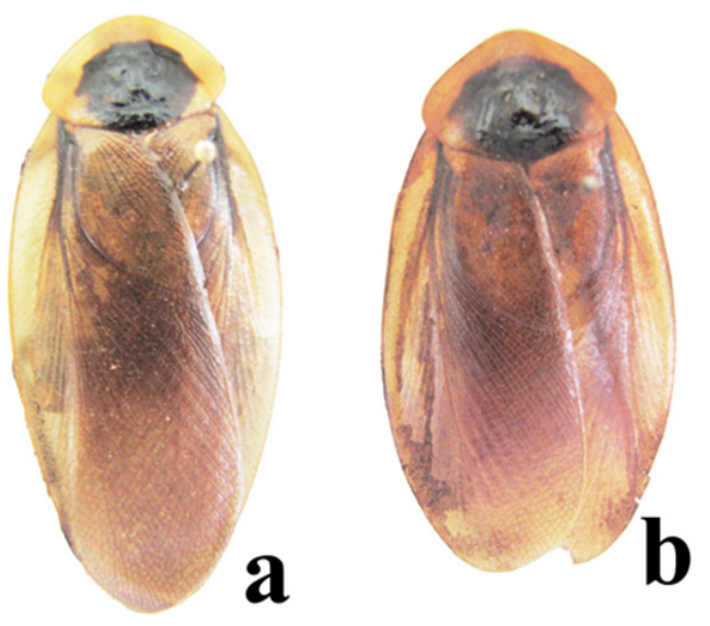

Figure 22. Brasilianus group. Blaberus parafusiformis sp. nov.: habitus. a. Goiás (52 mm); b. São Paulo (46 mm).

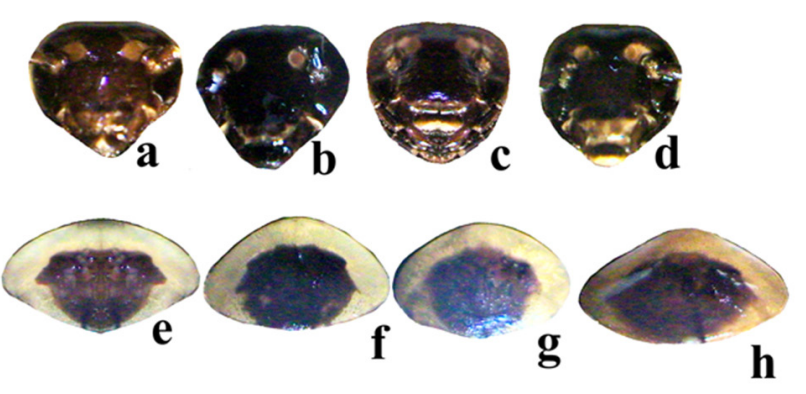

Figure 23. Brasilianus group. Blaberus parafusiformis sp. nov.: head, ventral (6 mm): a. São Paulo; b.,c., d. Goiás; pronotum, dorsal $(17 \mathrm{~mm})$ : e. São Paulo; f.,g.,h. Goiás. 
with longitudinal venule arrangement; ample anal field with nine or more axillary veins. Wings with small apical triangle and anal field folded fanlike.

Abdomen. Supra-anal and subgenital plates typical of the genus. In the genitalia, median sclerite with apex in shape of strongly sclerotized sac; prepuce with three or more rows of spines on left side, basal spines cristate; on right side, three rows of slightly larger spines on base of prepuce, bearing crests next to base of apex of median sclerite (Figure 24a-d); right phallomere hook-like, developed, with lateral edge fringed and slightly sclerotized; large pre-apical indentation and roundish and recurved apex with sclerotized internal structure (Figure 24e-h). Laminate left phallomere sclerotized and joined dorsally (Figure 24i-1).

Material examined. Holotype đ̊, Brazil, Rondônia, Ouro Preto, X/1980, A.C. Domingos col.; 3 Paratypes $\widehat{\partial}$, Goiás, Campinas, XII/1935, Borgmeier \& S. Lopes col.; Paratype $\widehat{\jmath}$, without locality, 04/XI/1927, A. M. Parko col.; Paratype +, São Paulo, VI/1928, D. Mendes, col.; Paratype $\hat{\jmath}$, Brazil, Mato Grosso, without date, Karloinsky col. (Museu de La Plata).

Comment: Four variations have been analyzed for the morphological characters of the head and the internal genitalia. The species is similar to $B$. fusiformis, differing in the spot on the pronotum which extends farther laterally, and in the configuration of the right phallomere, left phallomere and the median sclerite.

Etymology. The name of the species stems from its similarity to B. fusiformis.

\section{Blaberus nigrocephalicus sp. nov.}

In general the coloration is light yellowish-brown and shiny (Figure 25a). Dark-brown head; yellowish-brown ocellus and clypeus (Figure 25b); dark antennae with 15 basal articles shiny, other articles opaque with lighter tomentose. Dark legs with lighter pulvilli. Pronotum with dark-brown, almost black center-basal spot with narrow yellow band around apex (Figure 25c). Light tegmen with initial stem of veins marked by narrow dark-brown longitudinal
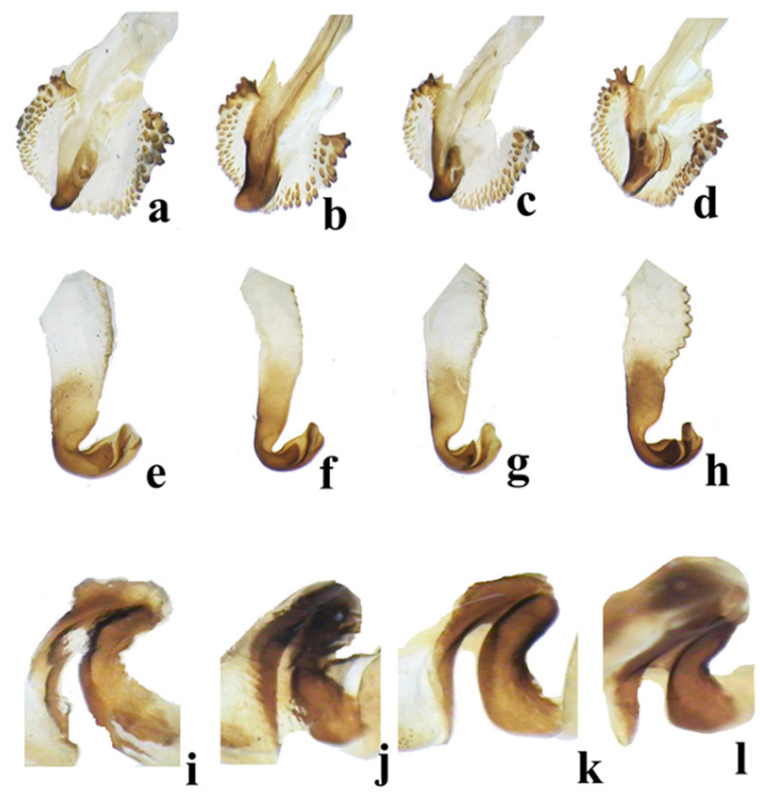

Figure 24. Brasilianus group. Blaberus parafusiformis sp. nov.: median sclerite, dorsal (2 mm). a.,b.,c. São Paulo; d. Goiás; right phallomere, dorsal (2 mm). e.,f.,g. São Paulo; h. Goiás; left phallomere, dorsal (2 mm). i, j, k. São Paulo; 1. Goiás. band. Abdomen with light-brown and yellowish tergites, and sternites with small dark-brown area in low relief next to lateral extremities.

Dimensions (mm). Total length: 70; length of pronotum: 14; width of pronotum: 20; length of tegmen: 63; width of tegmen: 21.

Subtriangular head with a roundish vertex exposed under pronotum in dorsal view; large eyes; interocular space narrow, almost united; spherical ocellus and deflected in relation to front; antennae tomentose and long, not reaching midlength of abdomen; post-clypeus slightly prominent; maxillar palpi with third and fifth articles larger than others, apical article dilated and tomentose.

Thorax. Elliptical, transverse pronotum with slightly deflected lateral edges; center-basal disc in shape of "feline face" with markings in low relief. Developed legs, cephalic femur with ventro-cephalic margin bearing three or four short robust spines followed by dense row of cilia towards apex, on which robust spine is inserted; middle and posterior femur with ventro-cephalic margin having small sparse cilia; ventro-caudal margin with dense row of cilia, larger than those on anterior face, plus one robust apical spine. Geniculate spine present. Pulvilli present on all tarsal articles; arolium absent, nails symmetrical and simple. Tegmen long, exceeding apex of cerci in length, deflected, elongated marginal field extending over middle of tegmen; short and narrow scapular field with longitudinal venule arrangement; ample discoidal field with veins in longitudinal, slightly angular arrangement; ample anal field. Developed wings, costal field having apex of radial vein branches not dilated; small apical triangle and anal field folded fanlike.

Abdomen. Supra-anal and subgenital plates typical of the genus. Genitalia with left phallomere in shape of two tapered laminas (Figure 25d); median sclerite with rounded sclerotized apex; prepuce of left side very elongated and tapered, with crest on base followed by two rows of spines which decrease in size up to the middle, and right side with similar arrangement (Figure 25e); right phallomere long and hook-shaped, with marked pre-apical indentation; apex with small acute dilation (Figure 25f).

Material examined. Holotype $\hat{\sigma}$, Brazil, Amazonas, Estirão do Equador, Rio Javari, X/1979, Alvarenga col.

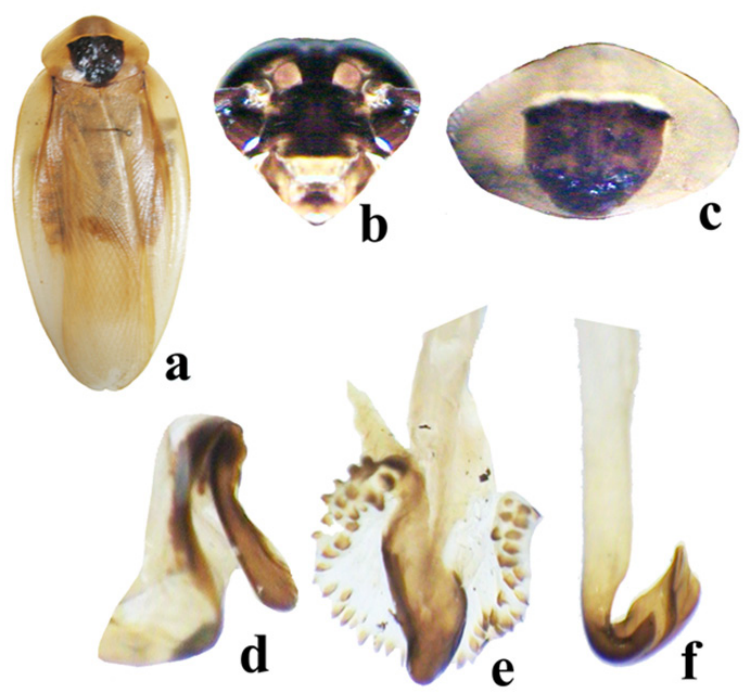

Figure 25. Brasilianus group. Blaberus nigrocephalicus sp. nov.: a. habitus (70 mm); b. head, ventral $(7 \mathrm{~mm})$; c. pronotum, dorsal $(19 \mathrm{~mm})$; d. left phallomere, dorsal (2 mm); e. median sclerite, dorsal $(2 \mathrm{~mm})$; f. right phallomere, dorsal (2 $\mathrm{mm})$. 
Comment. The species is similar to B. matogrossensis from the atropos group, differing in the pronotum coloration, the configuration of the right phallomere and the arrangement of spines on the prepuce.

Etymology. The name of the species is related to coloration of the head.

\section{Blaberus scutatus Saussure \& Zehntner, 1894}

B. scutatus Saussure \& Zenhtner, 1894: 119 (Blabera); Princis, 1963: 132; Rocha e Silva-Albuquerque, 1964:5; Roth, 1969: 220-221, 228; Vanschuyetbroeck, 1969: 6; Roth, 1970: 312, 319; Beccaloni, 2012: http://blattodea.speciesfile.org>; Pellens \& Grandcolas, 2008:44.

The species was well depicted by Roth (1969) (Figure 26a-g). Drawing upon the data and figures provided by Roth, six variations were analyzed. The head is black having ocellus and clypeus yellowish-brown (Figure 27a-f). The pronotum shows a nearly black central disc with a yellowish-brown spot with no definite shape (Figure $27 \mathrm{~g}-1$ ). In the male genitalia the right phallomere has a hooklike shape with a marked pre-apical incision (Figure 28a-g), the left phallomere laminate and sclerotized (Figure 28h-m) and the median sclerite with a sclerotized apex directed toward the apex, covered by the prepuce which bears more than one row of small spines and a crest on both sides (Figure 28n-t).

Material examined: $2 \hat{\jmath}$, Paraguay: Asunción; $1 \hat{\jmath}$ Brazil: Sergipe, Santo Amaro das Brotas; 2 ô, Bahia: Estação Biológica do Raso da Catarina, SEMA, Mata da Pororoca; 1 đ, Ceará, Timbaúbas,

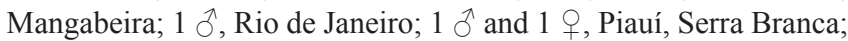
1 q, without locality.

Geographical distribution: Brazil (Piauí, Ceará, Rio Grande do Norte, Pernambuco, Sergipe, Bahia, Rio de Janeiro), Peru, Paraguay.

New records: Brazil (Ceará, Piauí, Sergipe, Bahia, Rio de Janeiro), Paraguay.

Blaberus valleyanus sp. nov.

General coloration light yellowish brown, shiny (Figure 29a). Brown head with darker eyes; yellowish ocellar spots and clypeus (Figure 29b). Dark-brown antennae and palpi golden-tomentose. Yellowish pronotum with dark-brown center-basal spot being of a 'peculiar shape' and with details in low relief, this spot with a narrow yellowish outline (Figure 29c). Clear tegmen with initial stem of all veins dark brown. Brown legs with ventro-basal parts of thighs
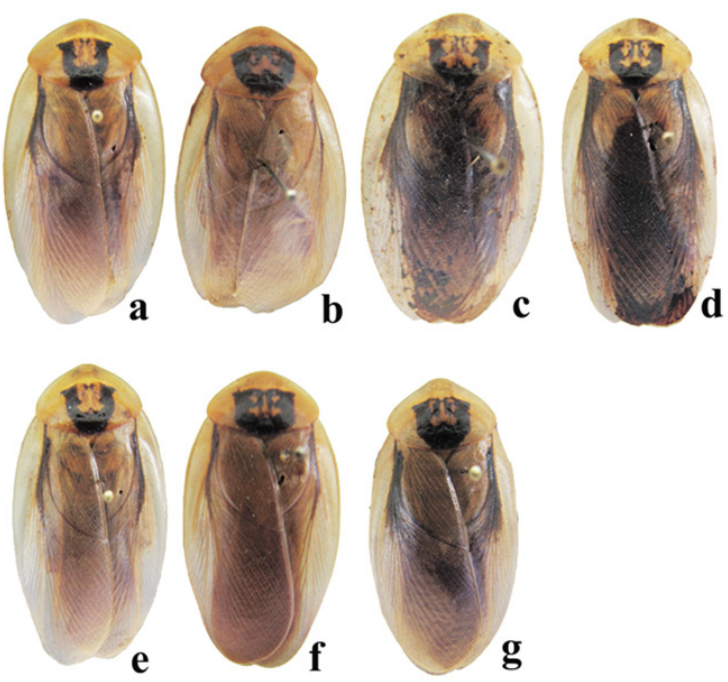

Figure 26. Brasilianus group. B. scutatus. habitus: a. Bahia $(55.3 \mathrm{~mm})$; b. Ceará (50.5 mm); c. Rio de Janeiro (52.0 mm); d. Piauí (49.2 mm); e. Bahia (52.3 mm); f. Paraguay (44.8 mm); g. Sergipe (48.4 mm). light; yellowish-brown pulvilli. Light yellowish-brown abdomen with sternites showing dark spots in low relief next to lateral edges.

Dimensions (mm). Total length 63.0; length of pronotum 13.0; width of pronotum 17.0; length of tegmen 53.0; width of tegmen 19.0.

Subtriangular head with roundish lateral-apical outline; vertex covered by pronotum in dorsal view; narrow interocular space,

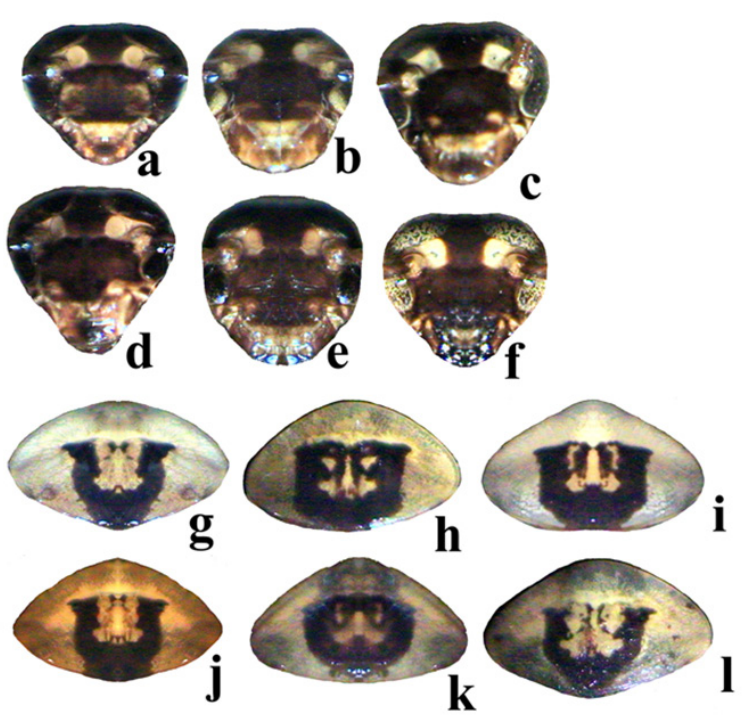

Figure 27. Brasilianus Group. B. scutatus. head: a. Bahia (7.4 mm); b. Paraguay $(7.0 \mathrm{~mm})$; c. Sergipe $(7.0 \mathrm{~mm})$; d. Bahia $(7.0 \mathrm{~mm})$; e. Ceará $(6.7 \mathrm{~mm})$; f. Rio de Janeiro $(7.0 \mathrm{~mm})$. pronotum: g. Bahia $(12.0 \mathrm{~mm})$; $\mathrm{h}$. Paraguay $(10.5 \mathrm{~mm})$; i. Sergipe $(11.0 \mathrm{~mm}) ;$ j. Bahia $(12.5 \mathrm{~mm})$; k. Ceará $(11.5 \mathrm{~mm})$; 1 . Rio de Janeiro $(11.5 \mathrm{~mm})$.
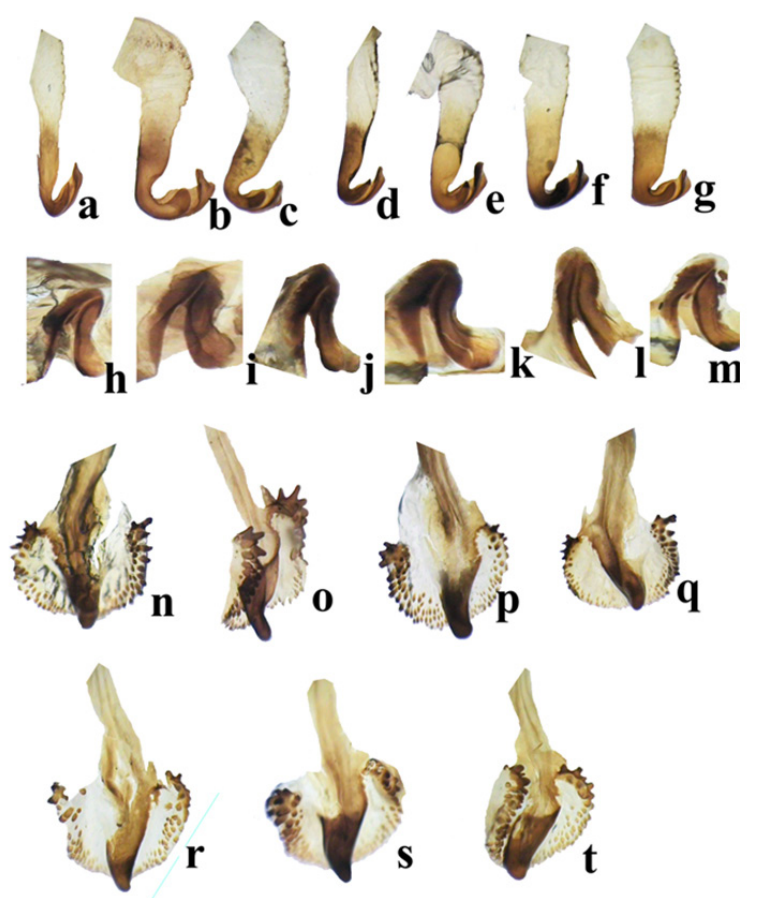

Figure 28. Brasilianus Group. B. scutatus: right phallomere, dorsal (2 mm). a. Bahia; b. Paraguay; c. Bahia; d. Rio de Janeiro; e. Sergipe; f. Ceará; g. Piauí; left phallomere, dorsal (2 mm). h. Bahia; i. Paraguai; j. Bahia; k. Sergipe; 1. Ceará; m. Piauí; median sclerite, dorsal (2 mm), n. Bahia; o. Paraguay; p. Sergipe; q. Bahia; r. Ceará; s. Rio de Janeiro; t. Piauí. 
measuring about one-fifth of distance between bases of antennal insertion; large and rounded ocellar spots; long antennae extending over apex of abdomen; developed and slightly prominent postclypeus; maxillar palpi with third article slightly larger than others, fourth and fifth articles dilated and tomentose.

Thorax. Elliptical, transverse pronotum with slight convexity showing median-apical region having a slightly prominent surface in relief. Strong and developed legs; cephalic femur with ventro-cephalic margin armed with four robust spines from base to middle, followed by dense row of ciliform spines extending to apex plus robust apical spine. Middle and posterior femurs with ventro-cephalic margin with spaced ciliform spines plus robust apical spine, ventro-caudal margin with dense row of ciliform spines extending to apex, with robust apical spine. Robust geniculate spine present on middle and posterior femurs. Tibias spiny, with apical outline forming crown of robust spines. Large pulvilli on all tarsal articles; symmetric and simple nails; arolium absent.

Long, spear-like tegmina exceeding apex of cerci in lengh; narrow marginal field; elongated scapular field with longitudinal venule arrangement. Developed wings; small apical triangle and anal field folded fanlike.

Abdomen. Supra-anal and subgenital plates typical of the genus. Left phallomere in two narrow laminas (Figure 29d), linguiform internal sclerotized structure. Recurved median sclerite which tapers toward strongly sclerotized apex; prepuce with row of spines on left side, and right side with two to three rows of rounded spines which decrease in size medially (Figure 29e). Right phallomere long and hook-shaped with large pre-apical indentation; apex wide and acute (Figure 29f).

Material examined.Holotype $\widehat{\jmath}$, Peru, Monson Valley, Tingo Maria, XII/1954, E.I. Schinger \& E.S. Ross cols.

Comment: Species similar to $B$. colosseus, differing in coloration of the pronotum and in the arrangement of the spines on the prepuce of the median sclerite.

Etymology: The species is named after the collection locality.

\section{3) Giganteus Group}

\section{Blaberus giganteus (Linnaeus, 1758)}

B. giganteus Linnaeus, 1758: 242; Bruijning, 1959: 3, 7-8; Princis, 1963: 122; Rocha e Silva-Albuquerque, 1964:5; Roth, 1969: 220-223; Vanschuyetbroeck, 1969:5; Roth, 1970: 310-311,

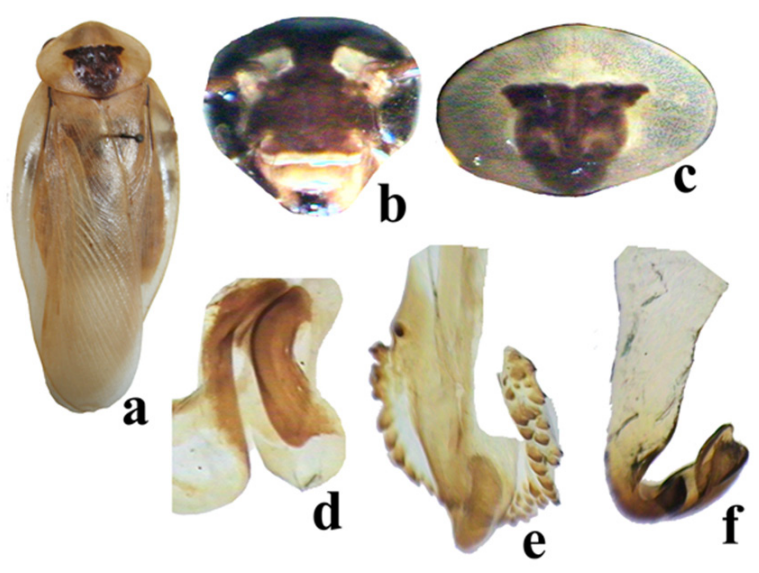

Figure 29. Brasilianus group. Blaberus valleyanus sp. nov.: a. habitus (63 mm); b. head, ventral $(7 \mathrm{~mm})$; c. pronotum, dorsal $(13 \mathrm{~mm})$; d. left phallomere, dorsal $(2 \mathrm{~mm})$; e. median sclerite, dorsal $(2 \mathrm{~mm})$; f. right phallomere, dorsal (2 $\mathrm{mm})$.
318; Rocha e Silva-Albuquerque, 1972:3; Jurberg et al., 1977:542; Pellens \& Grandcolas, 2008:44; Beccaloni, 2012: http://blattodea. speciesfile.org

B. giganteus (Figure 30a) is characterized by its black head with distinct ocellar spots and light-yellow clypeus (Figure 30b) and pronotum with compact black spot and two small white spots medially (Figure 30c). Few bristles on tegmina. In abdomen, genitalia long, and left phallomere formed of two narrow laminas that touch each other basally (Figure 30d), Median sclerite with tumor-like structure, noncontinuous with prepuce, and preputial spines numerous and small, in several rows (Figure 30e); right phallomere hook-shaped with sharp pre-apical indentations, and developed apex usually recurved upwards (Figure 30f).

Material examined: $1 \hat{\partial}$, Peru; Brazil: $1 \hat{\jmath}$ Amazonas; $1 \hat{\jmath}$ and

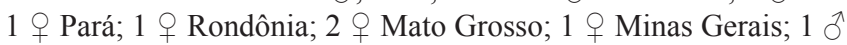
Espírito Santo; 1 \& Bahia.

Geographical distribution: U.S.A., West Indies, French Guiana, Panama, Mexico, Guatemala, Trinidad, Guyana, Suriname, Dominican Republic, Costa Rica, Nicaragua, Canada, Peru, Colombia, Venezuela, Brazil (Amapá, Amazonas, Pará, Pernambuco, Minas Gerais).

New records: Brazil (Rondônia, Mato Grosso, Espírito Santo, Bahia)

\section{Blaberus nigromaculatus sp. nov.}

General coloration light brown with blackened central spot on tegmina (Figure 31a). Head and antennas dark brown; ocellus, apex of clypeus and base of labrum light brown (Figure 31b). Pronotum brown with dark-brown center-basal spot (Figure 31c). Light-brown tegmina have an initial stem of veins, a small lateral part of anal area and transverse range at base of dark-brown discoidal area. Light brown pulvilli; thighs with light brownish-yellow ventral faces. Sternites with transverse apical range and lateral points in blackishbrown low relief.

Dimensions (mm): Holotype $\hat{\sigma}$ - Total length: 67.0; length of pronotum: 13.0; width of pronotum: 19.0; length of tegmen: 61.0; width of tegmen: 21.0 .

Head triangular, eyes reniform, vertex totally covered by pronotum, narrow interocular space measuring about one-eighth of distance between the bases where antennas are inserted; well-marked ocellus deflected in relation to head. Tomentose palpi.

Thorax with elliptical pronotum, transversum with two diverging furrows on central disc; lateral and apical edges deflected. Long tegmina, exceeding apex of cerci; long and narrow marginal field;

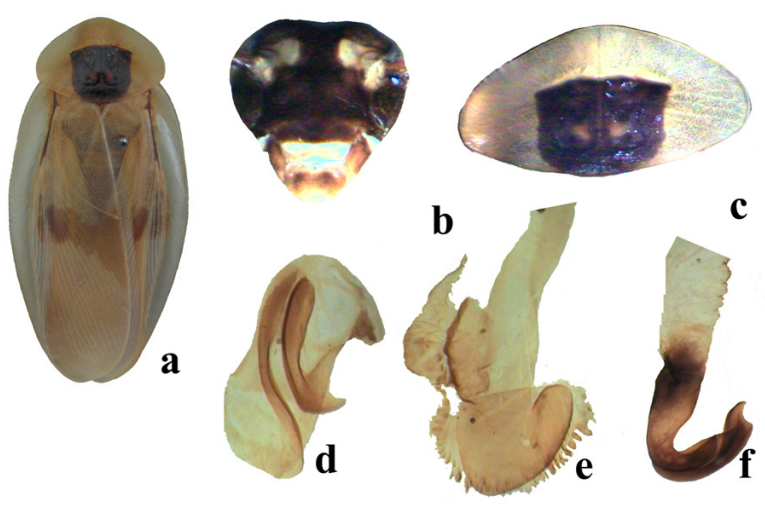

Figure 30. Giganteus group: B. giganteus. habitus: a. (70 mm); b. head, ventral (7 mm): c. pronotum, dorsal $(21 \mathrm{~mm})$ : d. left phallomere, dorsal $(2 \mathrm{~mm})$; e. median sclerite, dorsal (3 $\mathrm{mm})$; f. right phallomere, dorsal (2 mm). 
narrow scapular field; discoidal field with veins longitudinally arranged, slightly angular; ample anal field with nine axillary veins. Strong legs. Thigh with lateral-apical expansion on ventral surface; fore femur having ventro-cephalic margin with four small robust spines extending from base to middle, followed by dense row of cilia extending to apex, plus strong apical spine; ventro-caudal margin having sparse cilia and two small strong spines, one on apical third and the other apical. Middle and hind femurs, ventro-cephalic margin with sparse cilia and one strong apical spine, and ventro-caudal margin of middle femur with two spines, one on apical third and the other apical; hind femur without apical spine on ventro-caudal margin; pulvilli on all tarsal articles; symmetrical nails with no specialization; arolium absent.

Abdomen. Supra-anal and subgenital plates typical of the genus. Left phallomere with two narrow arms (Figure 31d). Median sclerite with small tumor-like structure continuous with prepuce, and many small preputial spines arranged in several rows (Figure 31e). Right phallomere long and hook-like, having very sharp pre-apical recesses, the apex is slightly widened and pointed (Figure 31f). Internal sclerotized linguiform structure.

Type Material: Holotype $\widehat{~}$, Brazil, Pará, Cachoeira do Arari, Ilha de Marajó, XI/1965, collector not identified.

Etymology: The name of the species is derived from the darkbrown spots on the tegmina.

Comment: $B$. nigromaculatus sp. nov. is distinguished from $B$. giganteus by the external coloration of the tegmina and head, and by the configuration of the median sclerite and right and left phallomeres.

4) Macurus Group (new group)

Blaberus macurus sp. nov.

General bright yellowish-brown coloration with dark-brown areas (Figure 32a). Head dark brown; ocellus, apex of clypeus and base of labrum yellowish (Figure 32b); palpi golden-tomentose; antennae dark, with first 15 articles shiny and others opaque. Pronotum lightcolored, with dark-brown central disk on base (Figure 32c). Tegmina light-colored, with initial stem of all veins almost black; scapular field, base of discoidal field, and apex of anal field all dark brown. Dark legs; internal ventral surface of thighs lighter-colored; light brown pulvilli. Abdomen brown with lighter outline.

Dimensions (mm). Holotype 9 . Total length: 88.0; length of pronotum: 19.0; width of pronotum: 25.0; length of tegmen: 76.0 ; width of tegmen: 27.0.

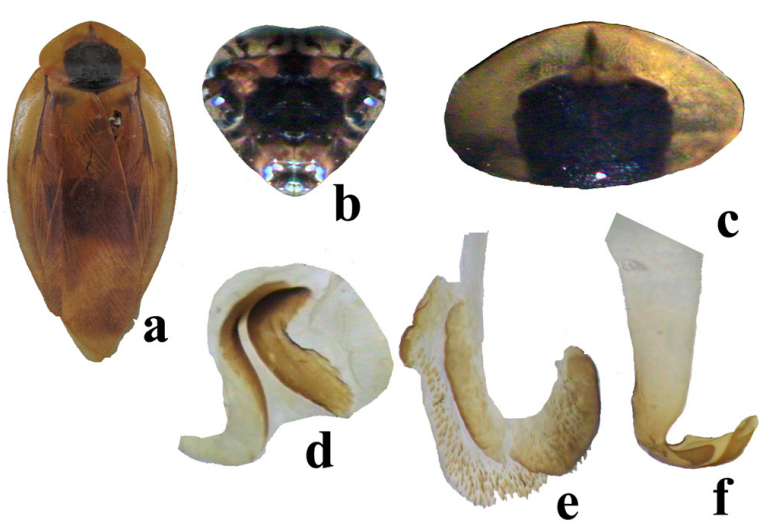

Figure 31. Giganteus group. Blaberus nigromaculatus sp. nov. a. habitus $(67 \mathrm{~mm})$; b. head, ventral $(6 \mathrm{~mm})$; c. pronotum, dorsal $(18 \mathrm{~mm})$; d. left phallomere, dorsal $(2 \mathrm{~mm})$; e. median sclerite, dorsal $(2 \mathrm{~mm})$; f. right phallomere, dorsal $(2 \mathrm{~mm})$.
Elliptical transverse pronotum having convexity more evident latero-apically. The head has the vertex totally covered by the pronotum; eyes reniform; narrow interocular space measuring about one-fifth distance between bases of antennae; large ocellus; antennae long, reaching midlength of abdomen. Maxillar palpi with third and fifth articles larger than others; fourth article dilated at apex, and apical article dilated and more tomentose. Tegmina long, exceeding apex of cerci; long, narrow and deflected marginal field; narrow scapular field; discoidal field long and wide, with longitudinal veins; ample anal field, with 12 axillary veins. Robust legs, thighs with outer ventral face bearing widened laminar apical projection. Fore femur with ventro-cephalic margin having three small spines, followed by dense row of minute cilia extending to apex, and strong apical spine; ventro-caudal margin with two small robust spines, one in apical third and the other apical; middle and hind femur with ventro-cephalic margin bearing sparse cilia plus one small, robust apical spine; ventrocaudal margin with dense row of cilia; middle femur with two apical spines, hind femur with no apical spines. Nails symmetrical, with no specialization; pulvilli present on all tarsal articles; arolia absent.

Abdomen. Supra-anal (Figure 32d) and subgenital (Figure 32e) plates typical of female Blaberus. Valves subequal in both shape and size, third pair larger than the others (Figure 32f).

Material examined: Holotype $q$, Venezuela, Macuro (Paria Peninsula), Edo. Sucre, 29/V/1964.

Etymology: The name of species is derived from the collection locality.

Comment: B. macurus sp. nov. is unique in its shape, size and color, although only the female is known. These differences allow us to allocate the species to a new group presented here (macurus group).

\section{Discussion}

The variety in general coloration of the individuals of Blaberus sometimes makes the study of the genus difficult. In the present study, these features were assessed and analyzed in parallel with the study of the genitalia, which allowed us to combine individuals with small variations in coloration on the tegmina, head or pronotum into a single species, drawing upon the analysis of their respective genital structures.

In $B$. atropos (Figure 2), the total length may range from 55 to $70 \mathrm{~mm}$ and the pronotum is typical in all samples of the atropos

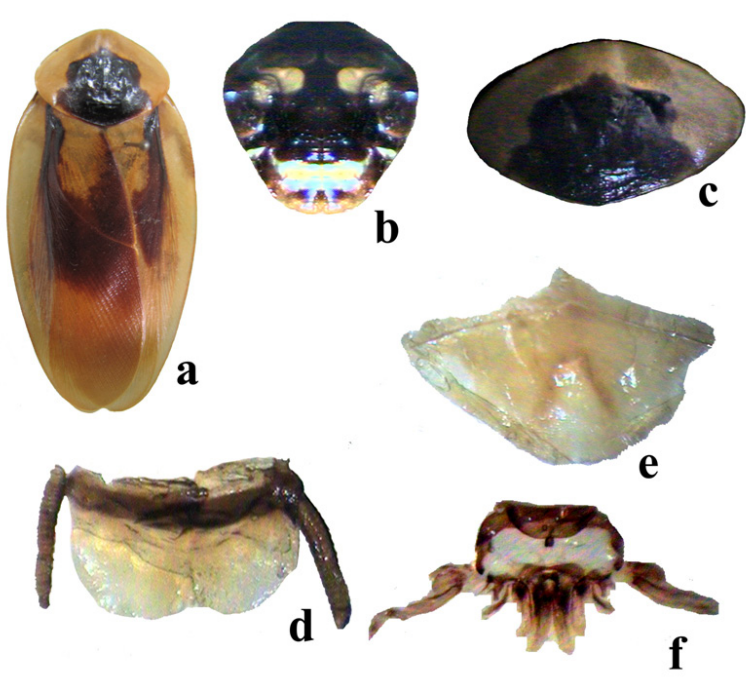

Figure 32. Macurus group. Blaberus macurus sp. nov. () a. habitus (88 mm); b. head, ventral (7 mm); c. pronotum, dorsal (25 mm); d. supra-anal plate, dorsal (12 mm); e. subgenital plate, ventral (20 mm); f. valves, dorsal (12 mm). 
group. A small variation from the general configuration was observed concerning the total length and the general coloration, in which the brown spot on the anal field of tegmen may extend or not. On the pronotum the compact central spot in all samples studied is straight anteriorly or slightly apically projected, as in Figure 4. The head coloration is homogeneous in all samples, but on the ocellus it may be more evident, as in Figure 3. In the male genitalia the general configuration is homogeneous, with a slight variation in the number of spines on the prepuce. On the right phallomere the degree of apical acuteness may vary, as in Figure 6. The configuration of the left phallomere does not vary.

The individuals identified as B. parabolicus (Figures 9-11) are very similar, with a small variation in total length (from 64 to $70 \mathrm{~mm}$ ) and in the coloration of the head and the pronotum, where a slight projection is observed (Figure 10). The morphology of the median sclerite and the right and left phallomere allows us to state that the samples belong to the same species.

In the brasilianus group, B. affinis (Figure 17) includes specimens with total length from 46 to $53 \mathrm{~mm}$, whose coloration is brown with darker veins in the tegmen; the pronotum has a central spot extending latero-apically. The specimens in Figures $18 \mathrm{c}$ and $18 \mathrm{~d}$ are similar in the coloration of the head, with slight variation in the coloration of the clypeus region. The habitus of the specimen shown in Figure 17d is not illustrated because the specimen was assembled with spread wings. The heads shown in Figures 18a and $18 \mathrm{~b}$ differ slightly in coloration and in the configuration of the right phallomere (Figures $18 \mathrm{~m}$ and $18 \mathrm{n}$ ) and the apex of the median sclerite is somewhat acute (Figures 18q and 18s); however, this character is not considered sufficient to identift these as separate species.

The specimens of B. neofusiformis (Figure 20) have total lengths ranging from 45 to $52 \mathrm{~mm}$ and a pronotum with a more marked median apical protuberance, which characterizes them as belonging to the brasilianus group. The coloration of the head and the pronotum differs slightly among the specimens (Figures 21a-e). However, the configuration of the median sclerite (Figures 21p-t) and other genital structures supports their retention within the species (Figures 21k-o and $21 \mathrm{u}-\mathrm{z})$.

In B. parafusiformis (Figure 22), the total length ranges from 46 $\mathrm{mm}$ to $52 \mathrm{~mm}$, and the central spot of the pronotum shows the same configuration in all the specimens studied. The head is darker, and the ocellus, although visible, is indistinct in its coloration (Figures 23b and 23c). The habitus of the specimens corresponding to the heads (Figures 23c and 23d) is not shown because they were assembled with spread wings. However, the configuration of the genital structures of all specimens is identical (Figures 24a-d, 24e-h, i-l).

The specimens characterized as B. scutatus (Figure 26) have total lengths ranging between 45 and $52 \mathrm{~mm}$. Seven variations of the species were distinguished. The coloration of the pronotum differs (Figure 27g-1), but the coloration of the head (Figures 27a-f) and the configuration of the genital structures leave no doubt that they belong to the same species (Figures 28a-g, h-m, n-t). Neither the head and the pronotum nor the left phallomere of all specimens are presented.

B. valleyanus sp. nov. (Figure 29a) corresponds to the species recorded by Roth (1969: 244) as Blaberus sp. (brasilianus group) from Tingo Maria, Peru.

\section{Acknowledgments}

We thank Dr. Solange Costa Garrido for translating the text into English, and Dr. Janet W. Reid for editing.

\section{References}

BECCALONI, G.W. 2012. Blattodea Species File Online. version 1.2/3.3. http://Blattodea.SpeciesFile.org (último acesso em 20/05/2008).
BRUNNER DE WATTENWYL, C. 1865. Nouveau système des Blattaires. Soc. I.R. Zool. Bot., Vienna, 426p.

BURMEISTER, H. 1838. Blattina. In Handbuch der Entomologie. I.C.F. Enslin, Berlin, v.2, n.2, p.469-517.

GURNEY, A.B., KRAMER, J.P. \& STEYSKAL, G.C. 1964. Some Techniques for the Preparation, Study and Storage in Microvials of Insect Genitalia. Ann. Entomol. Soc. Am. 57(2):240-242.

HEBARD, M. 1917. The Blattidae of North America north of the Mexican boundary. Mem. Am. Entomol. Soc. 2:1-284.

JURBERG, J., ROCHA E SILVA-ALBUQUERQUE, I., REBORDÕES, A.M.P., GONÇALVES, M.P. \& FELIPPE, M.L. 1977. Contribuição ao conhecimento de alguns Blaberidae da Coleção do Museu Nacional do Rio de Janeiro com um estudo morfológico da Genitália (Blattaria, Dictyoptera). Rev. Bras. Biol. 37(3):539-555.

KAMBHAMPATI, S. 1995. A phylogeny of cockroaches and related insects based on DNA sequence of mitochondrial ribosomal RNA genes. Proc. Natl. Acad. Sci. 92:2017-2020. http://dx.doi.org/10.1073/pnas.92.6.2017

KLASS, K.D. \& MEIER, R. 2006. A phylogenetic analysis of Dictyoptera (Insecta) based on morphological characters. Entomol. Abh. 63(1-2):3-50.

LEFÉUVRE, C. 1960. A propos de Blabera craniifer Burmeister 1838 (Insecte Dictyoptere). Bull. Soc. Sci. Bretagne 35 : 145-161.

LOPES, S.M. \& OLIVEIRA, E.H. 2000. Espécie nova de Eublaberus Hebard, 1919 do Estado de Goiás, BRASIL e notas sobre E. marajoara Rocha e Silva-Albuquerque, 1972 (Blaberidae, Blaberinae). Bol. Mus. Nac. Nova Sér. Zool., 433:1-5.

McKITTRICK, F.A. 1964. Evolutionary studies of cockroaches. Memoir Cornell Univ. Agric. Exp. Stn. 389:1-197.

PELLENS, R. \& GRANDCOLAS, P. 2008. Catalogue of Blattaria (Insecta) from Brazil. Zootaxa 1709:1-109.

PRINCIS, K. 1946. Drei neue neotropische Blattoden. Kungliga Fysiografiska Sällskapets I Lund Förhandlingar 16(17):159-166.

PRINCIS, K. 1963. Blattaria. In Orthopterorum Catalogus (M. Beier, ed.) W. Junk, Gravenhage, Pars 3, 4, 6, 7, 8, 11, 13, 14, 1224p.

ROCHA E SILVA-ALBUQUERQUE, I. 1964. Check-List dos Blattaria Brasileiros. Bol. Mus. Par. Emilio Goeldi Zool. 41:1-37.

ROTH, L.M. 1969. The evolution of male tergal glands in the Blattariae. Ann. Entomol. Soc. Am. 62:176-208.

ROTH, L.M. 1970. The male genitalia of Blattaria IV. Blaberidae: Blaberinae. Psyche, 77(2):217-236. http://dx.doi.org/10.1155/1970/14743

ROTH, L.M. 1976. The male genitalia of Blattaria. I. Blaberus spp. (Blaberidae: Blaberinae). Psyche 76:217-250. http://dx.doi.org/10.1155/1969/31394

ROTH, L.M. 2003. Systematics and Phylogeny of Cockroaches (Dictyoptera, Blattaria). Oriental Insects, 37:1-186. http://dx.doi.org/10.1080/003053 16.2003.10417344

SAUSSURE, H. \& ZEHNTNER, L. 1894. Insecta, Orthoptera, Blattidae. Biol. Centrali-Am. 1:13-123.

SERVILLE, J.G.A. 1831. Revue méthodique des insectes de l'ordre des Orthoptères. Ann. Sci. Nat. Zool. Biol. Anim. 22:166-167.

VANSCHUYTBROECK, P. 1969 Catalogue des Blattarie conservés dans les collections Entomologiques de l'Institut Royal des Sciences Naturelles de Belgique. Bull. Inst r. Sci. Nat. Belg. 46:1-20. 